\title{
LEVEL II SCOUR ANALYSIS FOR BRIDGE 33 (CONCTH00580033) on TOWN HIGHWAY 58, crossing MILES STREAM, CONCORD, VERMONT
}

U.S. Geological Survey Open-File Report 97-650

Prepared in cooperation with

VERMONT AGENCY OF TRANSPORTATION and

FEDERAL HIGHWAY ADMINISTRATION 


\section{LEVEL II SCOUR ANALYSIS FOR BRIDGE 33 (CONCTH00580033) on TOWN HIGHWAY 58, crossing MILES STREAM, CONCORD, VERMONT By RONDA L. BURNS}

U.S. Geological Survey Open-File Report 97-650

Prepared in cooperation with

VERMONT AGENCY OF TRANSPORTATION and

FEDERAL HIGHWAY ADMINISTRATION 


\title{
U.S. DEPARTMENT OF THE INTERIOR BRUCE BABBITT, Secretary
}

\author{
U.S. GEOLOGICAL SURVEY \\ Gordon P. Eaton, Director
}

For additional information write to:

District Chief

U.S. Geological Survey 361 Commerce Way

Pembroke, NH 03275-3718
Copies of this report may be purchased from:

U.S. Geological Survey

Branch of Information Services

Open-File Reports Unit

Box 25286

Denver, CO 80225-0286 


\section{CONTENTS}

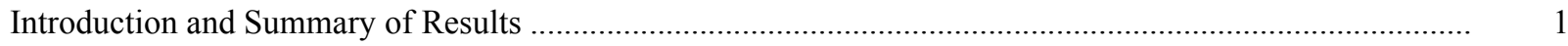

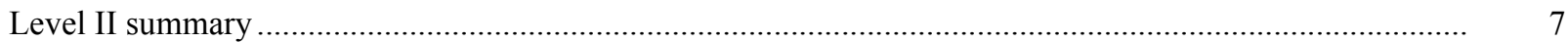

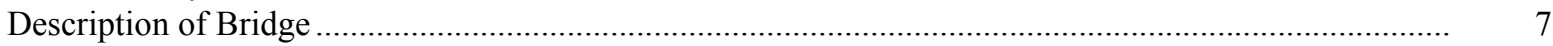

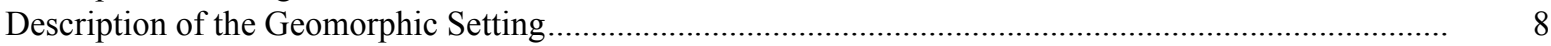

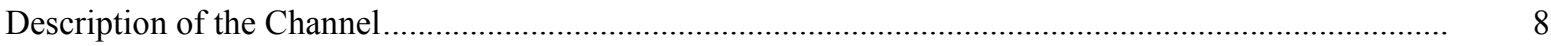

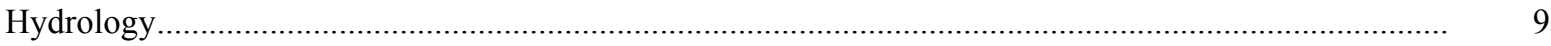

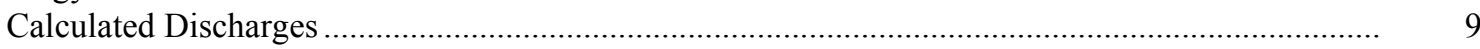

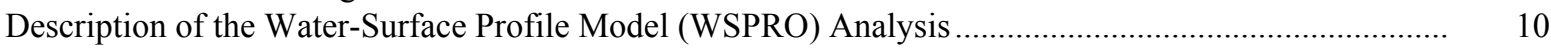

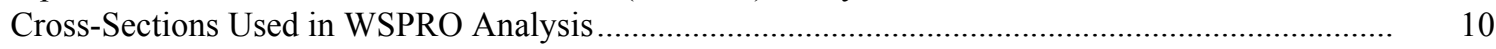

Data and Assumptions Used in WSPRO Model ...................................................................... 11

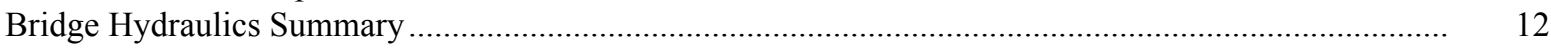

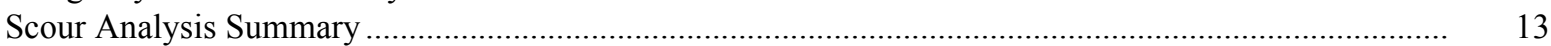

Special Conditions or Assumptions Made in Scour Analysis ...................................................... 13

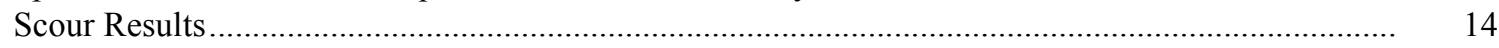

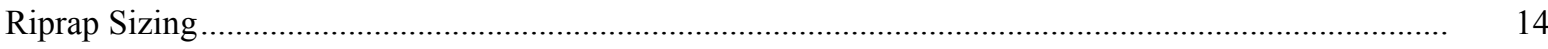

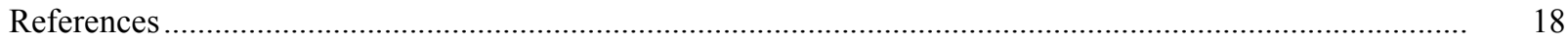

Appendixes:

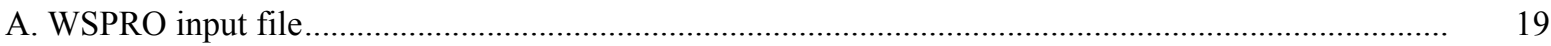

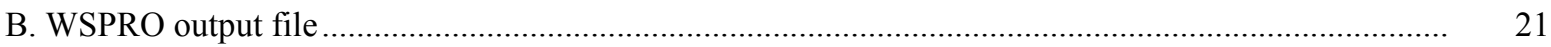

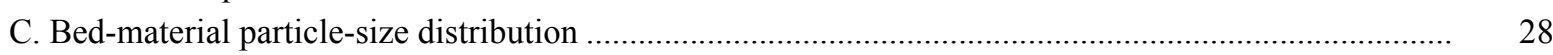

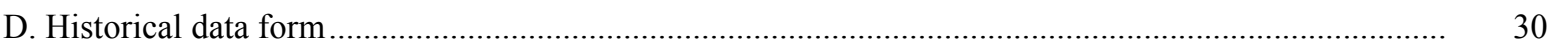

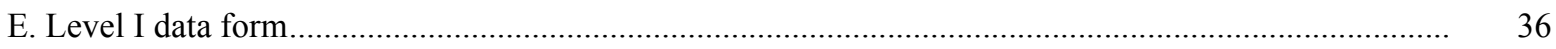

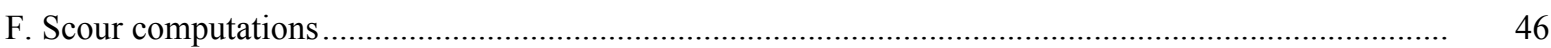

\section{FIGURES}

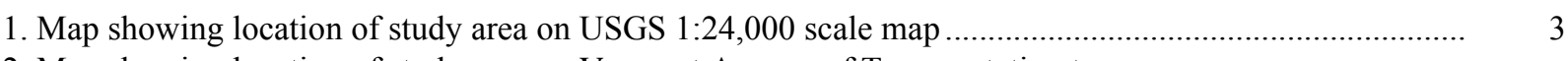

2. Map showing location of study area on Vermont Agency of Transportation town
highway map

3. Structure CONCTH00580033 viewed from upstream (August 15, 1995) …......................................... 5

4. Downstream channel viewed from structure CONCTH00580033 (August 15, 1995)........................... 5

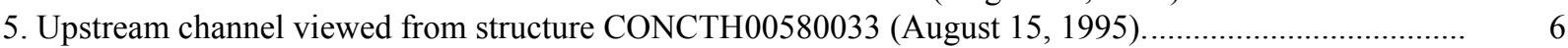

6. Structure CONCTH00580033 viewed from downstream (August 15, 1995). ..................................... 6

7. Water-surface profiles for the 100- and 500-year discharges at structure

CONCTH00580033 on Town Highway 58, crossing Miles Stream,

Concord, Vermont.

8. Scour elevations for the 100- and 500-year discharges at structure

CONCTH00580033 on Town Highway 58, crossing Miles Stream,

Concord, Vermont.

\section{TABLES}

1. Remaining footing/pile depth at abutments for the 100-year discharge at structure

CONCTH00580033 on Town Highway 58, crossing Miles Stream,

Concord, Vermont.....

2. Remaining footing/pile depth at abutments for the 500-year discharge at structure

CONCTH00580033 on Town Highway 58, crossing Miles Stream,

Concord, Vermont. 


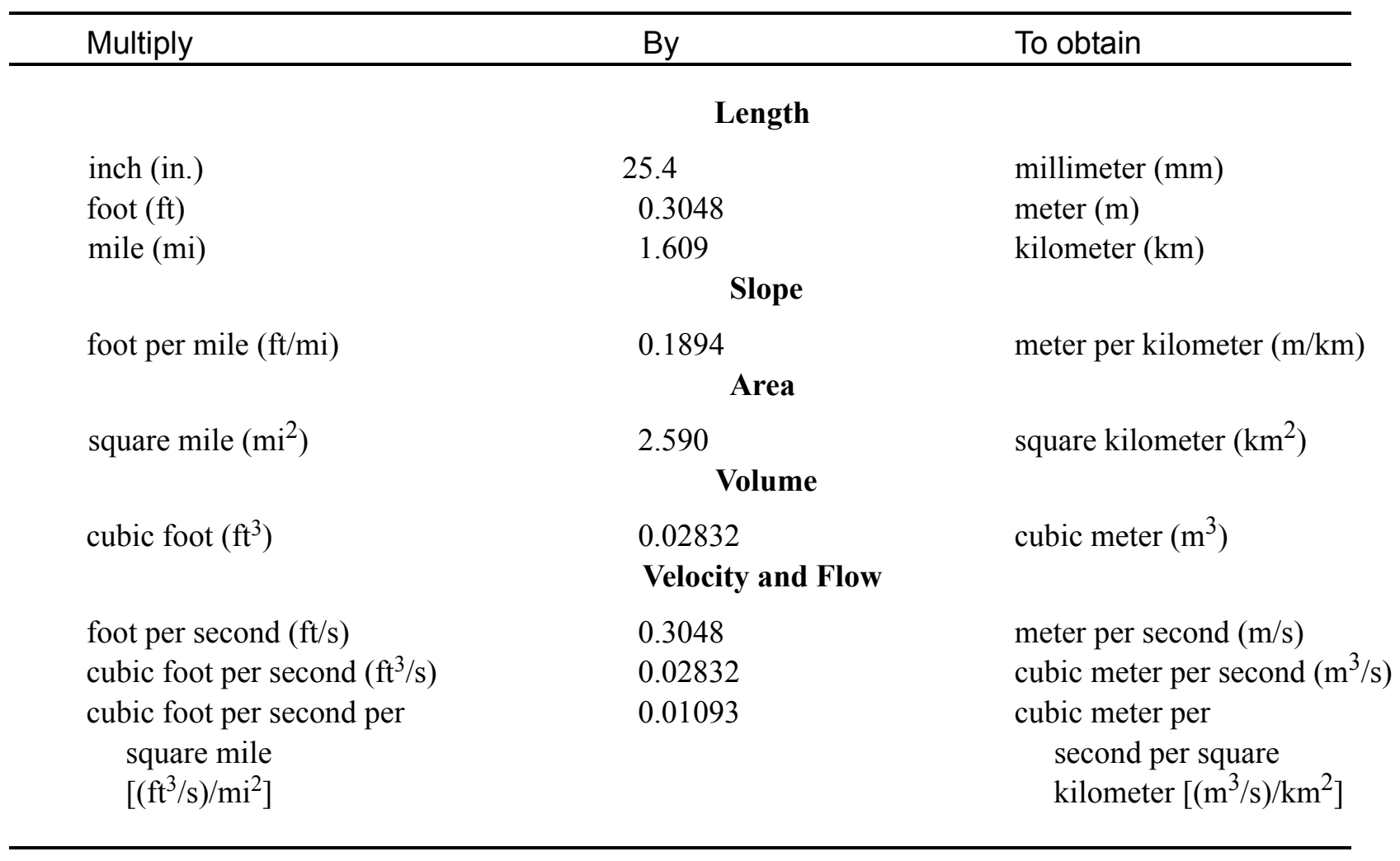

\section{OTHER ABBREVIATIONS}

$\begin{array}{lrlr}\mathrm{BF} & \text { bank full } & \text { LWW } & \text { left wingwall } \\ \mathrm{cfs} & \text { cubic feet per second } & \text { MC } & \text { main channel } \\ \mathrm{D}_{50} & \text { median diameter of bed material } & \text { RAB } & \text { right abutment } \\ \mathrm{DS} & \text { downstream } & \text { RABUT } & \text { face of right abutment } \\ \mathrm{elev} & \text { elevation } & \text { RB } & \text { right bank } \\ \mathrm{f} / \mathrm{p} & \text { flood plain } & \text { ROB } & \text { right overbank } \\ \mathrm{ft}^{2} & \text { square feet } & \text { RWW } & \text { right wingwall } \\ \mathrm{ft} / \mathrm{ft} & \text { feet per foot } & \text { TH } & \text { town highway } \\ \mathrm{JCT} & \text { junction } & \text { UB } & \text { under bridge } \\ \mathrm{LAB} & \text { left abutment } & \text { US } & \text { upstream } \\ \mathrm{LABUT} & \text { face of left abutment } & \text { USGS } & \text { United States Geological Survey } \\ \mathrm{LB} & \text { left bank } & \text { VTAOT Vermont Agency of Transportation } \\ \mathrm{LOB} & \text { left overbank } & \text { WSPRO } & \text { water-surface profile model }\end{array}$

In this report, the words "right" and "left" refer to directions that would be reported by an observer facing downstream. Sea level: In this report, "sea level" refers to the National Geodetic Vertical Datum of 1929-- a geodetic datum derived from a general adjustment of the first-order level nets of the United States and Canada, formerly called Sea Level Datum of 1929.

In the appendices, the above abbreviations may be combined. For example, USLB would represent upstream left bank. 


\title{
LEVEL II SCOUR ANALYSIS FOR BRIDGE 33 (CONCTH00580033) ON TOWN HIGHWAY 58, CROSSING MILES STREAM, CONCORD, VERMONT
}

\author{
By Ronda L. Burns
}

\section{INTRODUCTION AND SUMMARY OF RESULTS}

This report provides the results of a detailed Level II analysis of scour potential at structure CONCTH00580033 on Town Highway 58 crossing Miles Stream, Concord, Vermont (figures 1-8). A Level II study is a basic engineering analysis of the site, including a quantitative analysis of stream stability and scour (U.S. Department of Transportation, 1993). Results of a Level I scour investigation also are included in Appendix E of this report. A Level I investigation provides a qualitative geomorphic characterization of the study site. Information on the bridge, gleaned from Vermont Agency of Transportation (VTAOT) files, was compiled prior to conducting Level I and Level II analyses and is found in Appendix D.

The site is in the New England Upland section of the New England physiographic province in northeastern Vermont. The $17.9-\mathrm{mi}^{2}$ drainage area is in a predominantly rural and forested basin. In the vicinity of the study site, the surface cover is pasture upstream of the bridge while the immediate banks have dense woody vegetation. Downstream of the bridge, the right bank is forested and the left bank has shrubs and brush.

In the study area, Miles Stream has an incised, sinuous channel with a slope of approximately $0.01 \mathrm{ft} / \mathrm{ft}$, an average channel top width of $91 \mathrm{ft}$ and an average bank height of $7 \mathrm{ft}$. The channel bed material ranges from gravel to boulder with a median grain size $\left(\mathrm{D}_{50}\right)$ of $61.6 \mathrm{~mm}(0.188 \mathrm{ft})$. The geomorphic assessment at the time of the Level I and Level II site visit on August 15, 1995, indicated that the reach was stable.

The Town Highway 58 crossing of Miles Stream is a 44-ft-long, two-lane bridge consisting of one 39-foot steel-beam span (Vermont Agency of Transportation, written communication, March 24, 1995). The opening length of the structure parallel to the bridge face is $37.4 \mathrm{ft}$. The bridge is supported by vertical, concrete abutments with stone fill in front creating spillthrough embankments. The channel is skewed approximately 20 degrees to the opening while the opening-skew-to-roadway is zero degrees.

The only scour countermeasure at the site was type-3 stone fill (less than 48 inches diameter) along the left and right banks upstream, in front of the abutments forming spill through embankments, and extending along the banks downstream. Additional details describing conditions at the site are included in the Level II Summary and Appendices D and E. 
Scour depths and recommended rock rip-rap sizes were computed using the general guidelines described in Hydraulic Engineering Circular 18 (Richardson and others, 1995) for the 100- and 500-year discharges. In addition, the incipient roadway-overtopping discharge is determined and analyzed as another potential worst-case scour scenario. Total scour at a highway crossing is comprised of three components: 1) long-term streambed degradation; 2) contraction scour (due to accelerated flow caused by a reduction in flow area at a bridge) and; 3 ) local scour (caused by accelerated flow around piers and abutments). Total scour is the sum of the three components. Equations are available to compute depths for contraction and local scour and a summary of the results of these computations follows.

Contraction scour for all modelled flows ranged from 0.0 to $1.8 \mathrm{ft}$. The worst-case contraction scour occurred at the 500-year discharge. Abutment scour ranged from 4.0 to $9.7 \mathrm{ft}$. The worst-case abutment scour occurred at the 500-year discharge for the right abutment and at the incipient roadway-overtopping discharge for the left abutment. Additional information on scour depths and depths to armoring are included in the section titled "Scour Results". Scoured-streambed elevations, based on the calculated scour depths, are presented in tables 1 and 2. A cross-section of the scour computed at the bridge is presented in figure 8 . Scour depths were calculated assuming an infinite depth of erosive material and a homogeneous particle-size distribution.

It is generally accepted that the Froehlich equation (abutment scour) gives "excessively conservative estimates of scour depths" (Richardson and others, 1995, p. 47). Usually, computed scour depths are evaluated in combination with other information including (but not limited to) historical performance during flood events, the geomorphic stability assessment, existing scour protection measures, and the results of the hydraulic analyses. Therefore, scour depths adopted by VTAOT may differ from the computed values documented herein. 


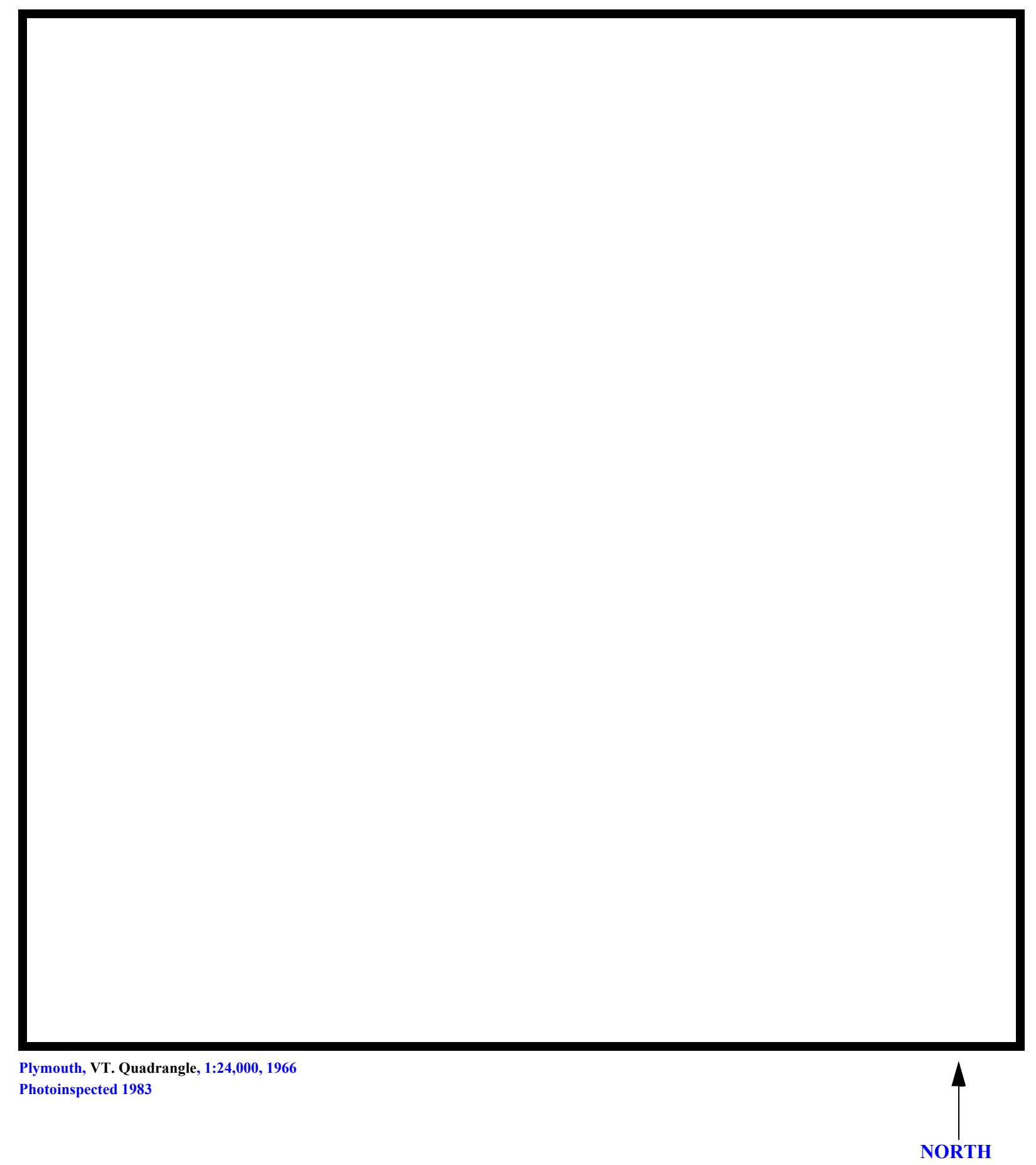

Figure 1. Location of study area on USGS 1:24,000 scale map. 
Figure 2. Location of study area on Vermont Agency of Transportation town highway map. 

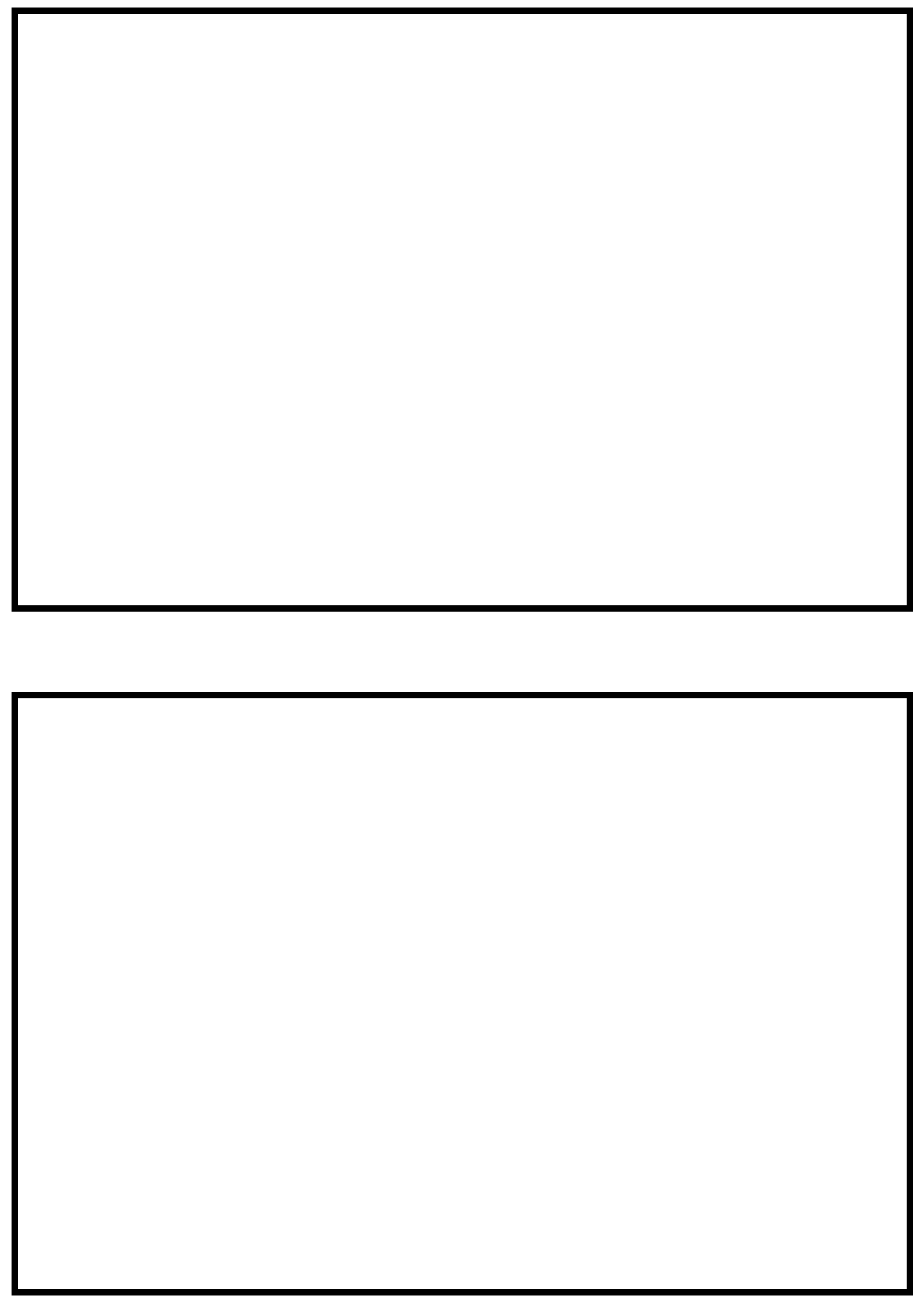

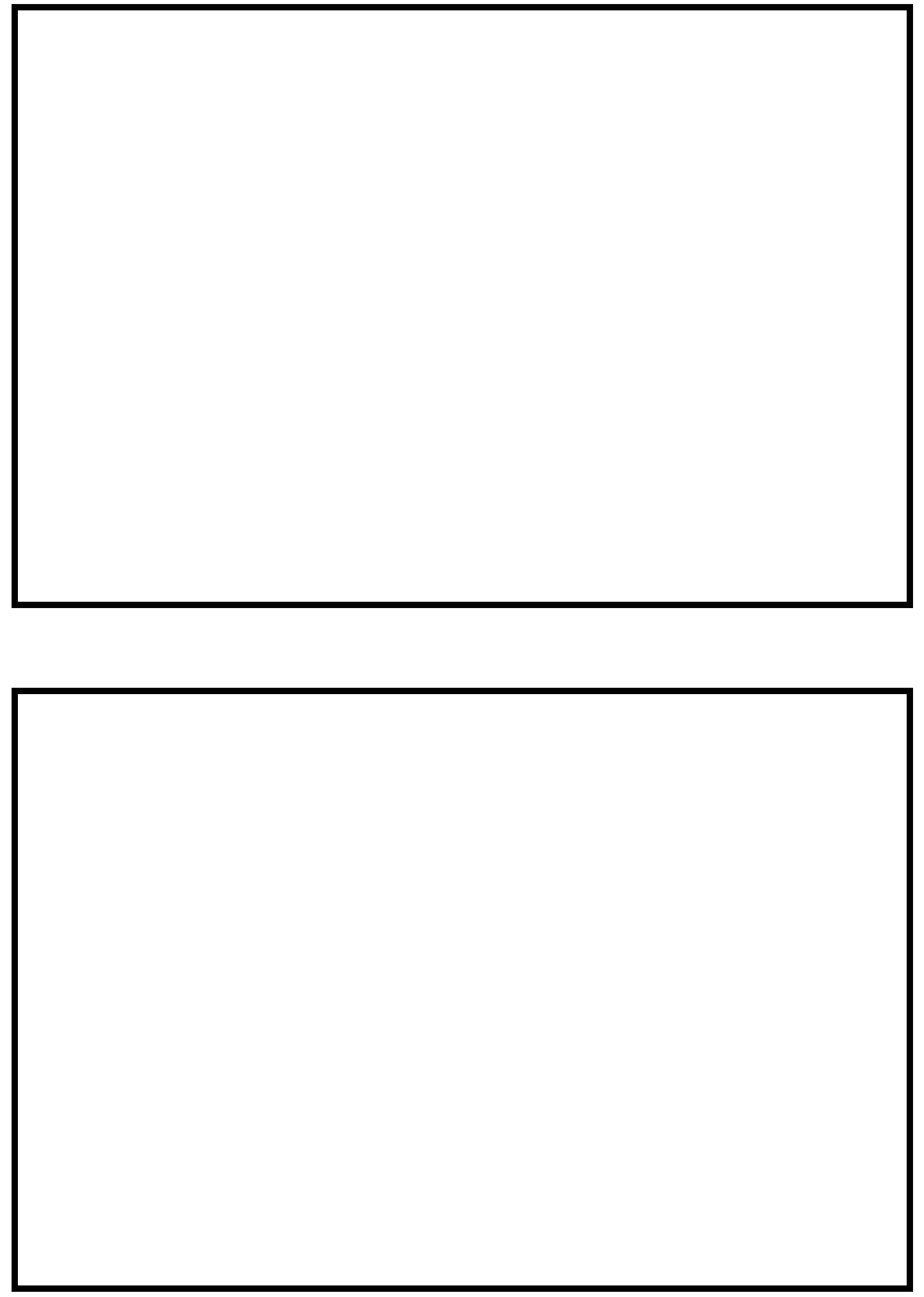


\section{LEVEL II SUMMARY}

\begin{tabular}{llllll} 
Structure Number & CONCTH00580033 & \multirow{2}{*}{ Stream } & \multicolumn{3}{c}{ Miles Stream } \\
& Road & TH 58 & District & 7 \\
County & Essex & Road & &
\end{tabular}

\section{Description of Bridge}

Bridge length $\stackrel{44}{n} \boldsymbol{f t} \quad$ Bridge width $\stackrel{20.6}{f t}$ Max span length $\stackrel{39}{ } \boldsymbol{f t}$ Alignment of bridge to road (on curve or straight)

\begin{tabular}{llll} 
Abutment type & \multicolumn{2}{c}{ Vertical, concrete } & None \\
Stone fill on abutment? & Yes & Embankment type & $8 / 15 / 95$ \\
& Type-3, along the entire baselength of both the left and right abutments
\end{tabular}
nacamintinu. af atan a fill Type-3, along the entire baselength of both the left and right abutments creating spill through slopes.

Abutments are concrete with spill through slopes of

stone fill in front.

Yes

20

Is bridge skewed to flood flow according to Yes 'survey? Angle

The stream bends moderately through the bridge.

Debris accumulation on bridge at time of Level I or Level II site visit:

\begin{tabular}{|c|c|c|c|}
\hline & $\begin{array}{c}\text { Date of insnortion } \\
8 / 15 / 95 \\
\end{array}$ & $\begin{array}{l}\text { Percent of alommol } \\
\text { blocked inortzontatly }\end{array}$ & $\begin{array}{l}\text { Percent of } 0 \\
\text { blocked verticatty }\end{array}$ \\
\hline el I & $8 / 15 / 95$ & 0 & 0 \\
\hline & Low. The & have sparse tree cover. & \\
\hline
\end{tabular}

Potential for debris

None as of 8/15/95.

Doscriho anv, fonturos noar ar at tho hridoo that mav, affort flou, (includo ahsorvation dato) 


\section{Description of the Geomorphic Setting}

General topography The channel is located within a moderate relief valley.

Geomorphic conditions at bridge site: downstream (DS), upstream (US)

Date of inspection $\quad 8 / 15 / 95$

DS left: $\quad$ Steep channel bank to a moderately sloped overbank.

DS right: $\quad$ Steep channel bank to a moderately sloped overbank.

US left: $\quad$ Steep channel bank to a moderately sloped overbank.

US right: $\quad$ Steep channel bank to a moderately sloped overbank.

\section{Description of the Channel}

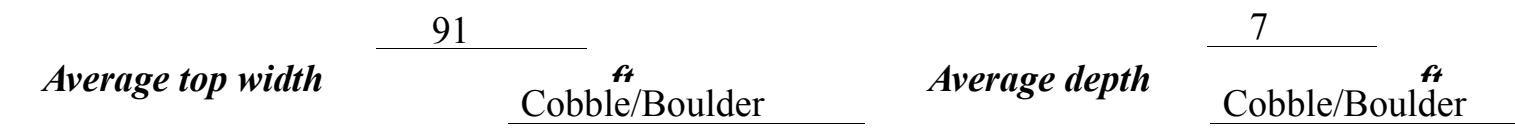

Predominant bed material

Bank material Sinuous but stable

with non-alluvial channel boundaries.

$8 / 15 / 95$

Vegetative co ${ }^{1}$ Shrubs and brush.

DS left: $\quad$ Trees.

DS right: $\quad$ Brush with short grass on the overbank.

US left: $\quad$ Brush with short grass on the overbank.

US right: $\quad$ Yes

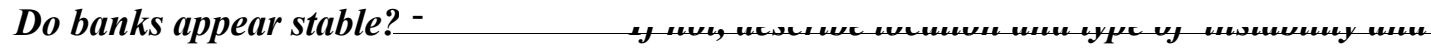

date of observatton.

The type-3 stone fill

along the abutments constricts the channel as of 8/15/95.

Describe any obstructions in channel and date of observation. 


\section{Hydrology}

Drainage area $\frac{17.9}{m_{i}{ }^{2}}$

Percentage of drainage area in physiographic provinces: (approximate)

Physiographic province/section New England/New England Upland
Percent of drainage area 100

Is drainage area considered rural or urban? Rural _ Describe any significant urbanization: There are houses on all the overbanks except the downstream right overbank.

No

Is there a USGS gage on the stream of interest?

USGS gage description

USGS gage number

Gage drainage area $\quad m^{2}$

Is there a lake/p

$-$ $-$

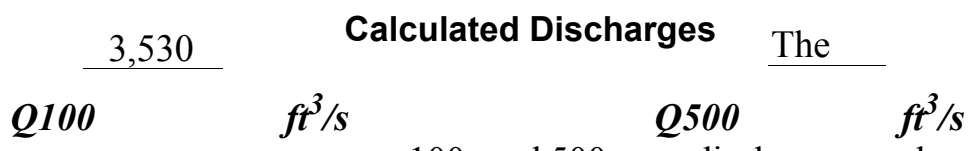

100- and 500-year discharges are based on a drainage

area relationship [(17.9/24.9)exp .0.67] with bridge number 34 in Concord. Bridge number 34 crosses the Miles Stream downstream of this site and has flood frequency estimates available from the VTAOT database. The drainage area above bridge number 34 is 24.9 square miles. The values used were within a range defined by flood frequency curves developed from several empirical methods (Benson, 1962; Johnson and Tasker, 1974; FHWA, 1983; Potter, 1957a\&b; Talbot, 1887). 


\section{Description of the Water-Surface Profile Model (WSPRO) Analysis}

Datum for WSPRO analysis (USGS survey, sea level, VTAOT plans)

USGS survey

Datum tie between USGS survey and VTAOT plans

None

Description of reference marks used to determine USGS datum. $\quad$ RM1 is a chiseled X on

top of the upstream left corner of the bridge deck (elev. $499.29 \mathrm{ft}$, arbitrary survey datum). RM2

is a chiseled $\mathrm{X}$ on top of the downstream right corner of the bridge deck (elev. $499.14 \mathrm{ft}$,

arbitrary survey datum).

\section{Cross-Sections Used in WSPRO Analysis}

\begin{tabular}{|c|c|c|c|}
\hline${ }^{1}$ Cross-section & $\begin{array}{c}\text { Section } \\
\text { Reference } \\
\text { Distance } \\
\text { (SRD) in feet }\end{array}$ & $\begin{array}{c}{ }^{2} \text { Cross-section } \\
\text { development }\end{array}$ & Comments \\
\hline EXIT1 & -39 & 1 & Exit section \\
\hline FULLV & 0 & 2 & $\begin{array}{l}\text { Downstream Full-valley } \\
\text { section (Templated from } \\
\text { EXITX) }\end{array}$ \\
\hline BRIDG & 0 & 1 & Bridge section \\
\hline RDWAY & 10 & 1 & Road Grade section \\
\hline APTEM & 46 & 1 & $\begin{array}{l}\text { Approach section as sur- } \\
\text { veyed (Used as a tem- } \\
\text { plate) }\end{array}$ \\
\hline APPR 1 & 58 & 2 & $\begin{array}{l}\text { Modelled Approach sec- } \\
\text { tion (Templated from } \\
\text { APTEM) }\end{array}$ \\
\hline
\end{tabular}

${ }^{1}$ For location of cross-sections see plan-view sketch included with Level I field form, Appendix E. For more detail on how cross-sections were developed see WSPRO input file. 


\section{Data and Assumptions Used in WSPRO Model}

Hydraulic analyses of the reach were done by use of the Federal Highway Administration's WSPRO step-backwater computer program (Shearman and others, 1986, and Shearman, 1990). The analyses reported herein reflect conditions existing at the site at the time of the study. Furthermore, in the development of the model it was necessary to assume no accumulation of debris or ice at the site. Results of the hydraulic model are presented in the Bridge Hydraulic Summary, Appendix B, and figure 7.

Channel roughness factors (Manning's “ $n$ ”) used in the hydraulic model were estimated using field inspections at each cross section following the general guidelines described by Arcement and Schneider (1989). Final adjustments to the values were made during the modelling of the reach. Channel " $\mathrm{n}$ " values for the reach ranged from 0.045 to 0.050 , and overbank " $n$ " values ranged from 0.040 to 0.060 .

Normal depth at the exit section (EXIT1) was assumed as the starting water surface. This depth was computed by use of the slope-conveyance method outlined in the user's manual for WSPRO (Shearman, 1990). The slope used was $0.0133 \mathrm{ft} / \mathrm{ft}$, which was estimated from the topographic map (U.S. Geological Survey, 1967).

The surveyed approach section (APTEM) was moved along the approach channel slope $(0.0076 \mathrm{ft} / \mathrm{ft})$ to establish the modelled approach section (APPR1), one bridge length upstream of the upstream face as recommended by Shearman and others (1986). This location also provides a consistent method for determining scour variables. 


\section{Bridge Hydraulics Summary}

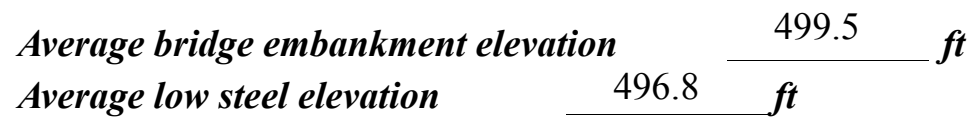

100-year discharge $\quad 2,550 \quad \mathrm{ft}^{3} / \mathrm{s}$

Water-surface elevation in bridge opening $\quad 497.0 \quad f t$

Road overtopping? ___ Yes Discharge over road __ $324 \quad \mathrm{ft}^{3} / \mathrm{s}$

\begin{tabular}{lll} 
Area of flow in bridge opening & $238 \quad \mathrm{ft}^{2}$ \\
\cline { 2 - 3 } Average velocity in bridge opening & 9.4 & $\mathrm{ft} / \mathrm{s}$
\end{tabular}

$\begin{array}{llll}\text { Maximum WSPRO tube velocity at bridge } & 11.7 & \mathrm{ft} / \mathrm{s}\end{array}$

Water-surface elevation at Approach section with bridge 499.4

Water-surface elevation at Approach section without bridge $\quad 495.3$

Amount of backwater caused by bridge 4.1 it

500-year discharge $\quad 3,530 \quad \mathrm{ft}^{3} / \mathrm{s}$

Water-surface elevation in bridge opening $\quad 496.8 \mathrm{ft}$

Road overtopping? ___ Yes Discharge over road _ $1,140, \% / s$

Area of flow in bridge opening $\quad 236 \quad \mathrm{ft}^{2}$

Average velocity in bridge opening $10.1 \mathrm{ft} / \mathrm{s}$

Maximum WSPRO tube velocity at bridge 14.5 's

Water-surface elevation at Approach section with bridge 500.1

Water-surface elevation at Approach section without bridge $\quad 496.4$

Amount of backwater caused by bridge $\quad 3.7, t$

Incipient overtopping discharge $\quad 1,810 \mathrm{ft}^{3} / \mathrm{s}$

Water-surface elevation in bridge opening $497.0 \quad t$

Area of flow in bridge opening $\quad 238 \quad \mathrm{ft}^{2}$

Average velocity in bridge opening $\quad 7.6 \quad \mathrm{ft} / \mathrm{s}$

Maximum WSPRO tube velocity at bridge $\quad 9.5 \mathrm{ft} / \mathrm{s}$

Water-surface elevation at Approach section with bridge

Water-surface elevation at Approach section without bridge

Amount of backwater caused by bridge $\quad 3.9$, $t$

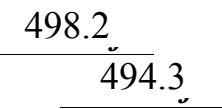




\section{Scour Analysis Summary}

\section{Special Conditions or Assumptions Made in Scour Analysis}

Scour depths were computed using the general guidelines described in Hydraulic Engineering Circular 18 (Richardson and others, 1995). Scour depths were calculated assuming an infinite depth of erosive material and a homogeneous particle-size distribution. The results of the scour analysis are presented in tables 1 and 2 and a graph of the scour depths is presented in figure 8 .

At this site, the 100-year, 500-year and incipient roadway-overtopping discharges resulted in unsubmerged orifice flow. Contraction scour at bridges with orifice flow is best estimated by use of the Chang pressure-flow scour equation (oral communication, J. Sterling Jones, October 4, 1996). Thus, contraction scour for these discharges was computed by use of the Chang equation (Richardson and others, 1995, p. 145-146). The computed streambed armoring depths suggest that armoring will not limit the depth of contraction scour.

For comparison, contraction scour for the discharges resulting in orifice flow was also computed by use of the Laursen clear-water contraction scour equation (Richardson and others, 1995, p. 32, equation 20) and the Umbrell pressure-flow equation (Richardson and others, 1995, p. 144) and presented in Appendix F. Furthermore, since the discharges resulted in unsubmerged orifice flow, contraction scour was computed by substituting estimates for the depth of flow at the downstream bridge face in the contraction scour equations. Results with respect to these substitutions are provided in Appendix F.

Abutment scour for the right abutment was computed by use of the Froehlich equation (Richardson and others, 1995, p. 48, equation 28). Variables for the Froehlich equation include the Froude number of the flow approaching the embankments, the length of the embankment blocking flow, and the depth of flow approaching the embankment less any roadway overtopping.

Scour at the left abutment was computed by use of the HIRE equation (Richardson and others, 1995, p. 49, equation 29) because the HIRE equation is recommended when the length to depth ratio of the embankment blocking flow exceeds 25 . The variables used by the HIRE abutment-scour equation are defined the same as those defined for the Froehlich abutment-scour equation. 


\section{Scour Results}

100-yr discharge 500-yr discharge

Contraction scour:

(Scour depths in feet)

Main channel

Live-bed scour

Clear-water scour

Depth to armoring

Left overbank

Right overbank

Local scour:

Abutment scour

Left abutment

4.0

4.0

7.4

8.8

$9.7-$

$7.7-$

Right abutment

Pier scour

Pier 1

Pier 2

Pier 3

Abutments:

Left abutment

Right abutment

Piers:

Pier 1

Pier 2

\section{Riprap Sizing}

Incipient overtopping 100-yr discharge 500-yrdischarge discharge

2.3

2.3

$--$

$--$

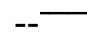
( $D_{50}$ in feet)

$2.3 \quad 2.0$

$2.3 \quad 2.0$

$\longrightarrow$

$-{ }^{-}$

$--$

$-$

$---$ 


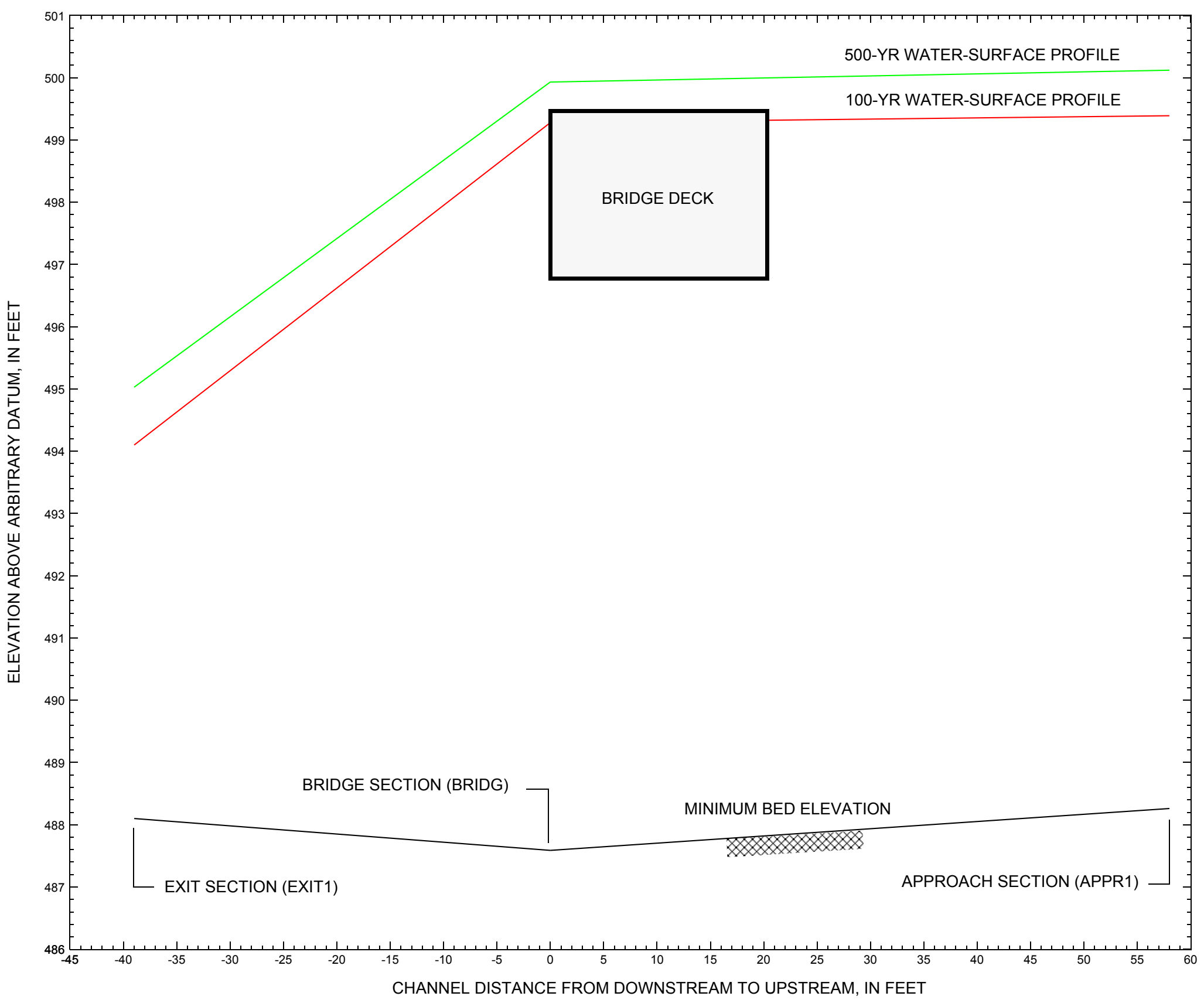

Figure 7. Water-surface profiles for the 100- and 500-yr discharges at structure CONCTH00580033 on Town Highway 58, crossing Miles Stream, Concord, Vermont. 


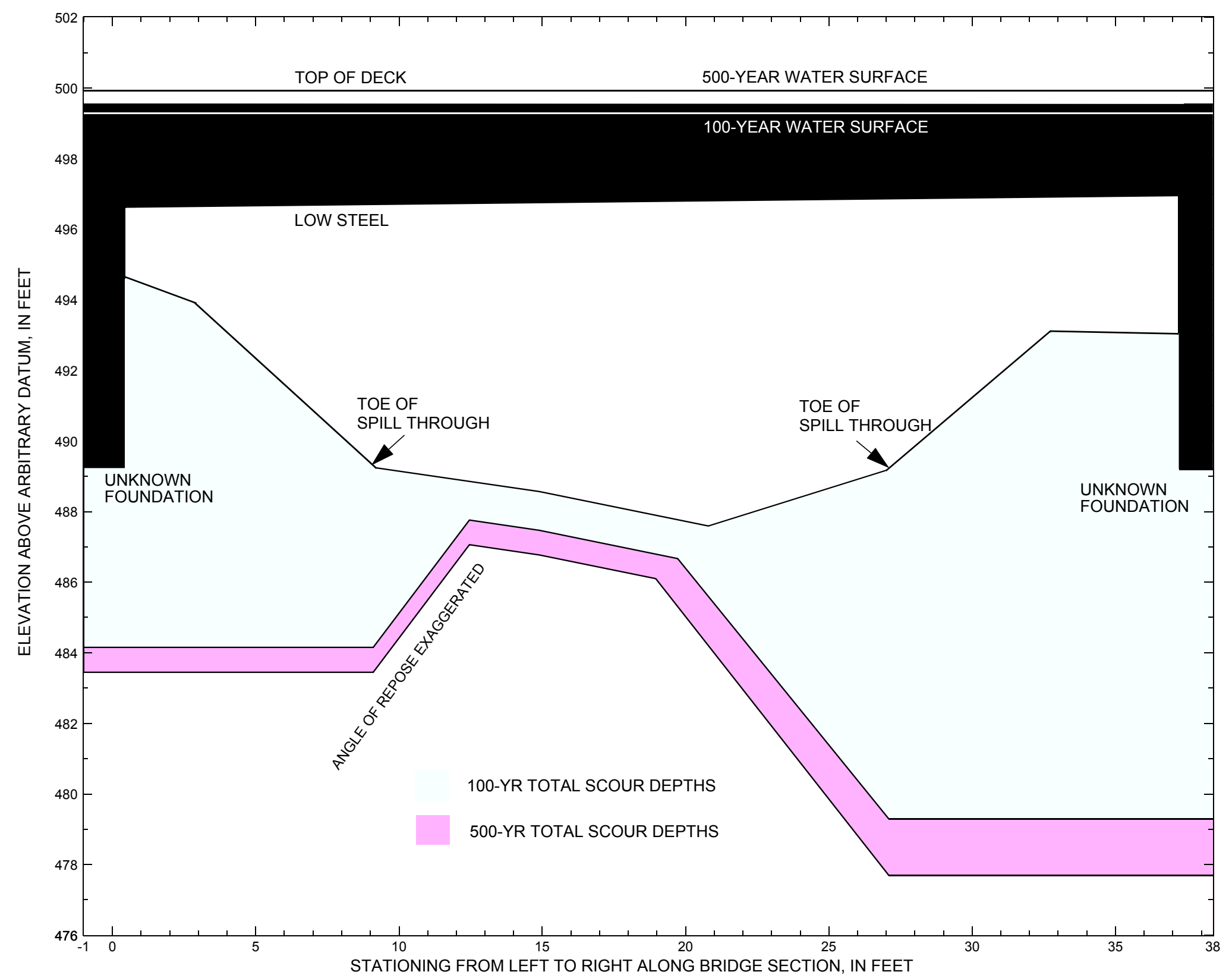

Figure 8. Scour elevations for the 100-yr and 500-yr discharges at structure CONCTH00580033 on Town Highway 58, crossing Miles Stream, Concord, Vermont. 
Table 1. Remaining footing/pile depth at abutments for the 100-year discharge at structure CONCTH00580033 on Town Highway 58, crossing Miles Stream, Concord, Vermont.

[VTAOT, Vermont Agency of Transportation; --, no data]

\begin{tabular}{|c|c|c|c|c|c|c|c|c|c|c|c|}
\hline Description & Station $^{1}$ & $\begin{array}{l}\text { VTAOT } \\
\text { minimum } \\
\text { low-chord } \\
\text { elevation } \\
\text { (feet) }\end{array}$ & $\begin{array}{c}\text { Surveyed } \\
\text { minimum } \\
\text { low-chord } \\
\text { elevation } \\
\text { (feet) }\end{array}$ & $\begin{array}{c}\text { Bottom of } \\
\text { footing/pile } \\
\text { elevation } \\
\text { (feet) }\end{array}$ & $\begin{array}{l}\text { Channel } \\
\text { elevation at } \\
\text { abutment/ } \\
\text { pier }^{2} \\
\text { (feet) }\end{array}$ & $\begin{array}{l}\text { Contraction } \\
\text { scour depth } \\
\text { (feet) }\end{array}$ & $\begin{array}{l}\text { Abutment } \\
\text { scour } \\
\text { depth } \\
\text { (feet) }\end{array}$ & $\begin{array}{l}\text { Pier } \\
\text { scour } \\
\text { depth } \\
\text { (feet) }\end{array}$ & $\begin{array}{l}\text { Depth of } \\
\text { total scour } \\
\text { (feet) }\end{array}$ & $\begin{array}{c}\text { Elevation of } \\
\text { scour }^{2} \\
\text { (feet) }\end{array}$ & $\begin{array}{c}\text { Remaining } \\
\text { footing/pile } \\
\text { depth } \\
\text { (feet) }\end{array}$ \\
\hline \multicolumn{12}{|c|}{100 -yr. discharge is 2,550 cubic-feet per second } \\
\hline Left abutment & 0.0 & -- & 496.6 & -- & 494.6 & -- & -- & -- & -- & -- & -- \\
\hline Toe of LABUT & 9.1 & -- & -- & -- & 489.2 & 1.1 & 4.0 & -- & 5.1 & 484.1 & -- \\
\hline Toe of RABUT & 27.1 & -- & -- & -- & 489.2 & 1.1 & 8.8 & -- & 9.9 & 479.3 & -- \\
\hline Right abutment & 37.4 & -- & 497.0 & -- & 493.0 & -- & -- & -- & -- & -- & -- \\
\hline
\end{tabular}

1.Measured along the face of the most constricting side of the bridge.

2.Arbitrary datum for this study.

Table 2. Remaining footing/pile depth at abutments for the 500-year discharge at structure CONCTH00580033 on Town Highway 58, crossing Miles Stream, Concord, Vermont.

[VTAOT, Vermont Agency of Transportation; --, no data]

\begin{tabular}{|c|c|c|c|c|c|c|c|c|c|c|c|}
\hline Description & Station $^{1}$ & $\begin{array}{l}\text { VTAOT } \\
\text { minimum } \\
\text { low-chord } \\
\text { elevation } \\
\text { (feet) }\end{array}$ & $\begin{array}{c}\text { Surveyed } \\
\text { minimum } \\
\text { low-chord } \\
\text { elevation } \\
\text { (feet) }\end{array}$ & $\begin{array}{c}\text { Bottom of } \\
\text { footing/pile } \\
\text { elevation }{ }^{2} \\
\text { (feet) }\end{array}$ & $\begin{array}{c}\text { Channel } \\
\text { elevation at } \\
\text { abutment/ } \\
\text { pier }^{2} \\
\text { (feet) }\end{array}$ & $\begin{array}{c}\text { Contraction } \\
\text { scour depth } \\
\text { (feet) }\end{array}$ & $\begin{array}{l}\text { Abutment } \\
\text { scour } \\
\text { depth } \\
\text { (feet) }\end{array}$ & $\begin{array}{l}\text { Pier } \\
\text { scour } \\
\text { depth } \\
\text { (feet) }\end{array}$ & $\begin{array}{l}\text { Depth of } \\
\text { total scour } \\
\text { (feet) }\end{array}$ & $\begin{array}{c}\text { Elevation of } \\
\text { scour }^{2} \\
\text { (feet) }\end{array}$ & $\begin{array}{c}\text { Remaining } \\
\text { footing/pile } \\
\text { depth } \\
\text { (feet) }\end{array}$ \\
\hline \multicolumn{12}{|c|}{500 -yr. discharge is 3,530 cubic-feet per second } \\
\hline Left abutment & 0.0 & -- & 496.6 & -- & 494.6 & -- & -- & -- & -- & -- & -- \\
\hline Toe of LABUT & 9.1 & -- & -- & -- & 489.2 & 1.8 & 4.0 & -- & 5.8 & 483.4 & -- \\
\hline Toe of RABUT & 27.1 & -- & -- & -- & 489.2 & 1.8 & 9.7 & -- & 11.5 & 477.7 & -- \\
\hline Right abutment & 37.4 & -- & 497.0 & -- & 493.0 & -- & -- & -- & -- & -- & -- \\
\hline
\end{tabular}

1.Measured along the face of the most constricting side of the bridge.

2.Arbitrary datum for this study. 


\section{SELECTED REFERENCES}

Arcement, G.J., Jr., and Schneider, V.R., 1989, Guide for selecting Manning's roughness coefficients for natural channels and flood plains: U.S. Geological Survey Water-Supply Paper 2339, 38 p.

Barnes, H.H., Jr., 1967, Roughness characteristics of natural channels: U.S. Geological Survey Water-Supply Paper 1849,213 p.

Benson, M. A., 1962, Factors Influencing the Occurrence of Floods in a Humid Region of Diverse Terrain: U.S. Geological Survey WaterSupply Paper 1580-B, 64 p.

Brown, S.A. and Clyde, E.S., 1989, Design of riprap revetment: Federal Highway Administration Hydraulic Engineering Circular No. 11, Publication FHWA-IP-89-016, 156 p.

Federal Highway Administration, 1983, Runoff estimates for small watersheds and development of sound design: Federal Highway Administration Report FHWA-RD-77-158.

Federal Highway Administration, 1993, Stream Stability and Scour at Highway Bridges: Participant Workbook: Federal Highway Administration Report FHWA-HI-91-011.

Froehlich, D.C., 1989, Local scour at bridge abutments in Ports, M.A., ed., Hydraulic Engineering--Proceedings of the 1989 National Conference on Hydraulic Engineering: New York, American Society of Civil Engineers, p. 13-18.

Hayes, D.C.,1993, Site selection and collection of bridge-scour data in Delaware, Maryland, and Virginia: U.S. Geological Survey WaterResources Investigation Report 93-4017, 23 p.

Interagency Advisory Committee on Water Data, 1982, Guidelines for determining flood flow frequency: U.S. Geological Survey, Bulletin 17B of the Hydrology Subcommittee, 190 p.

Johnson, C.G. and Tasker, G.D.,1974, Progress report on flood magnitude and frequency of Vermont streams: U.S. Geological Survey OpenFile Report 74-130, 37 p.

Lagasse, P.F., Schall, J.D., Johnson, F., Richardson, E.V., Chang, F., 1995, Stream Stability at Highway Structures: Federal Highway Administration Hydraulic Engineering Circular No. 20, Publication FHWA-IP-90-014, 144 p.

Laursen, E.M., 1960, Scour at bridge crossings: Journal of the Hydraulics Division, American Society of Civil Engineers, v. 86, no. HY2, p. 39-53.

Potter, W. D., 1957a, Peak rates of runoff in the Adirondack, White Mountains, and Maine woods area, Bureau of Public Roads

Potter, W. D., 1957b, Peak rates of runoff in the New England Hill and Lowland area, Bureau of Public Roads

Richardson, E.V. and Davis, S.R., 1995, Evaluating scour at bridges: Federal Highway Administration Hydraulic Engineering Circular No. 18, Publication FHWA-IP-90-017, 204 p.

Richardson, E.V., Simons, D.B., and Julien, P.Y., 1990, Highways in the river environment: Federal Highway Administration Publication FHWA-HI-90-016.

Ritter, D.F., 1984, Process Geomorphology: W.C. Brown Co., Debuque, Iowa, 603 p.

Shearman, J.O., 1990, User's manual for WSPRO--a computer model for water surface profile computations: Federal Highway Administration Publication FHWA-IP-89-027, 187 p.

Shearman, J.O., Kirby, W.H., Schneider, V.R., and Flippo, H.N., 1986, Bridge waterways analysis model; research report: Federal Highway Administration Publication FHWA-RD-86-108, 112 p.

Talbot, A.N., 1887, The determination of water-way for bridges and culverts.

U.S. Department of Transportation, 1993, Stream stability and scour at highway bridges, Participant Workbook: Federal Highway Administration Publication FHWA HI-91-011.

U.S. Geological Survey, 1967, Miles Pond, Vermont 7.5 Minute Series quadrangle map: U.S. Geological Survey Topographic Maps, Photoinspected 1983, Scale 1:24,000. 


\section{APPENDIX A: \\ WSPRO INPUT FILE}




\section{WSPRO INPUT FILE}

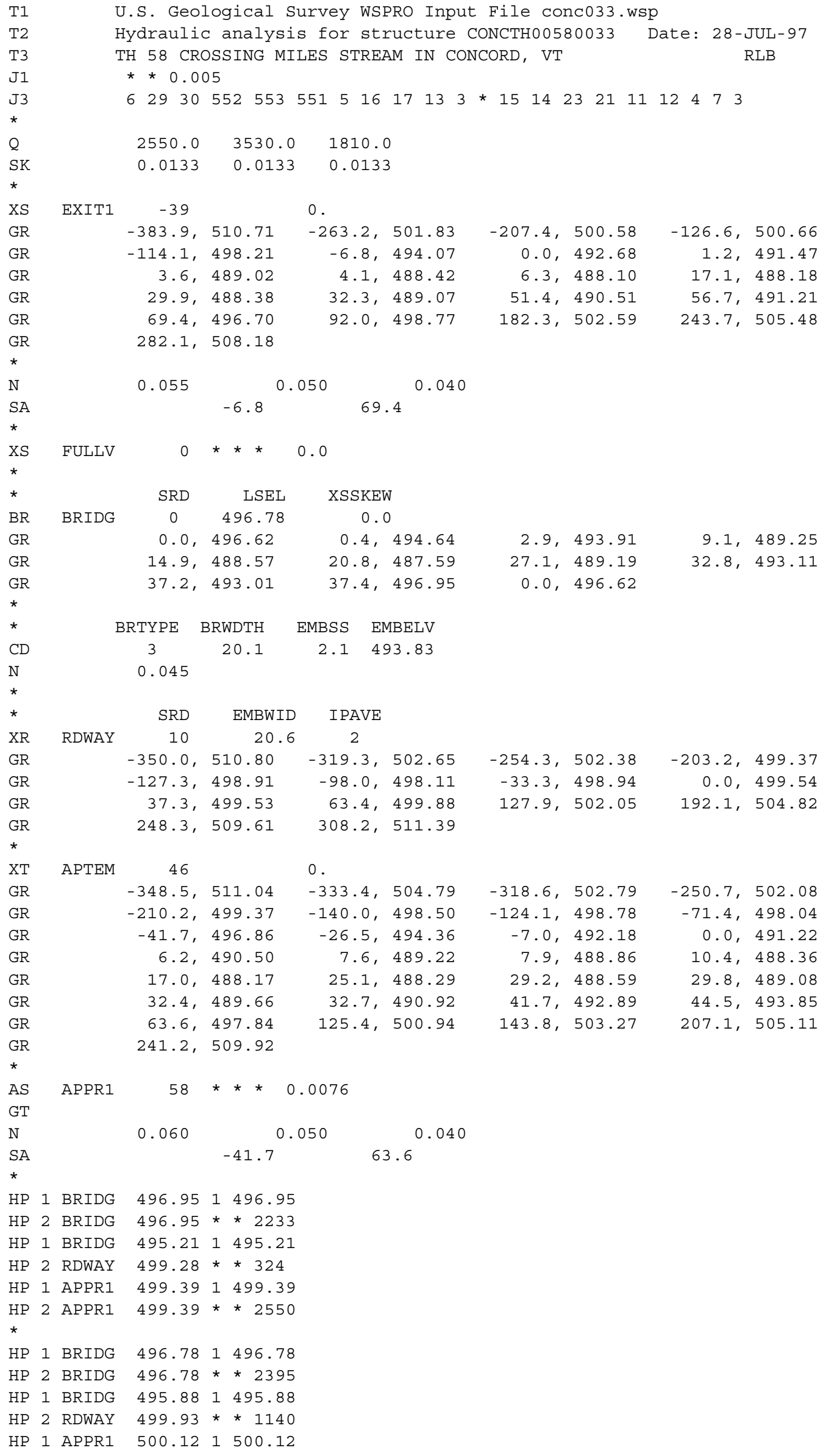




\section{APPENDIX B: \\ WSPRO OUTPUT FILE}




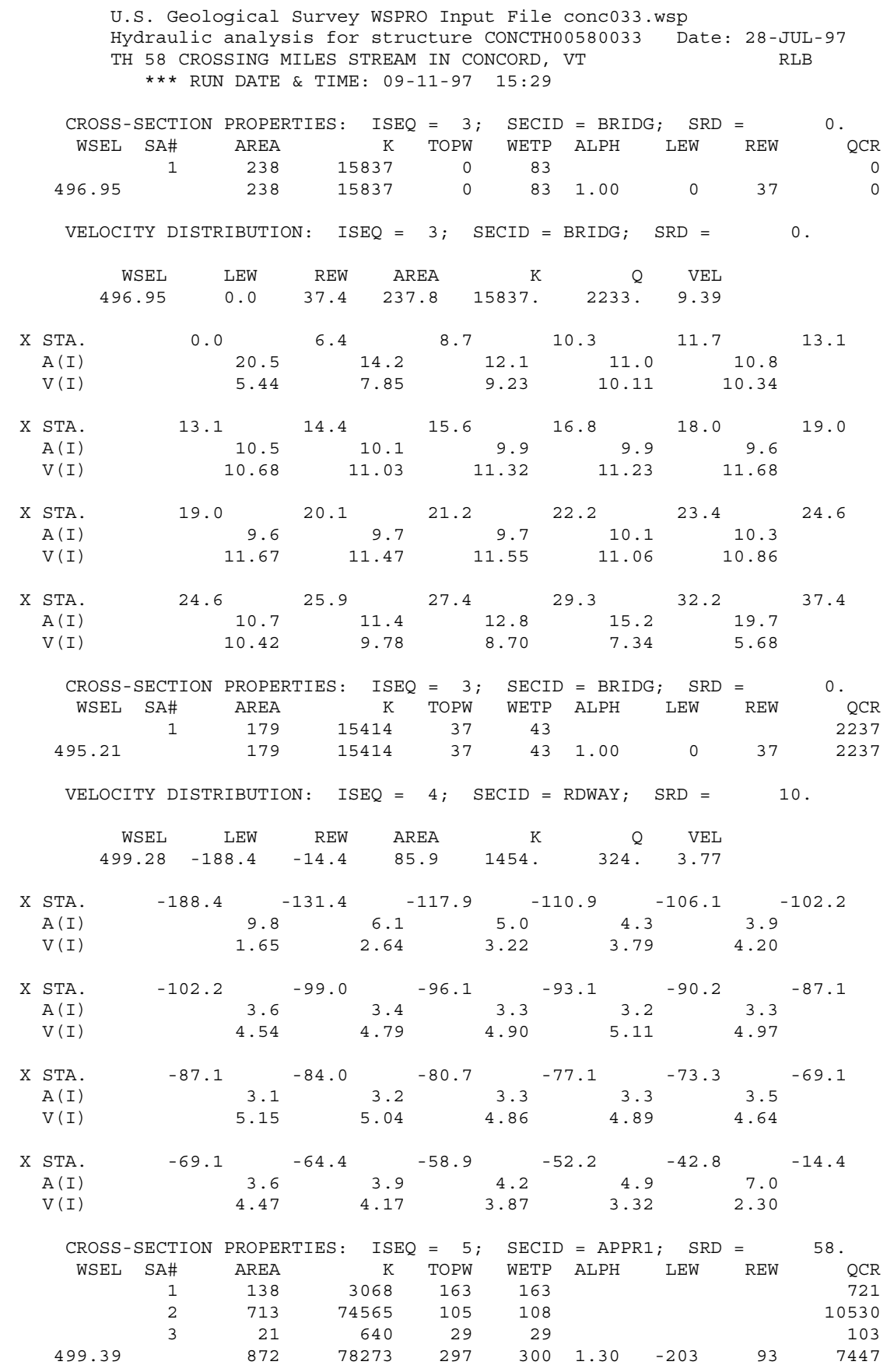

VELOCITY DISTRIBUTION: ISEQ $=5 ;$ SECID $=$ APPRI; $\quad$ SRD $=\quad 58$.

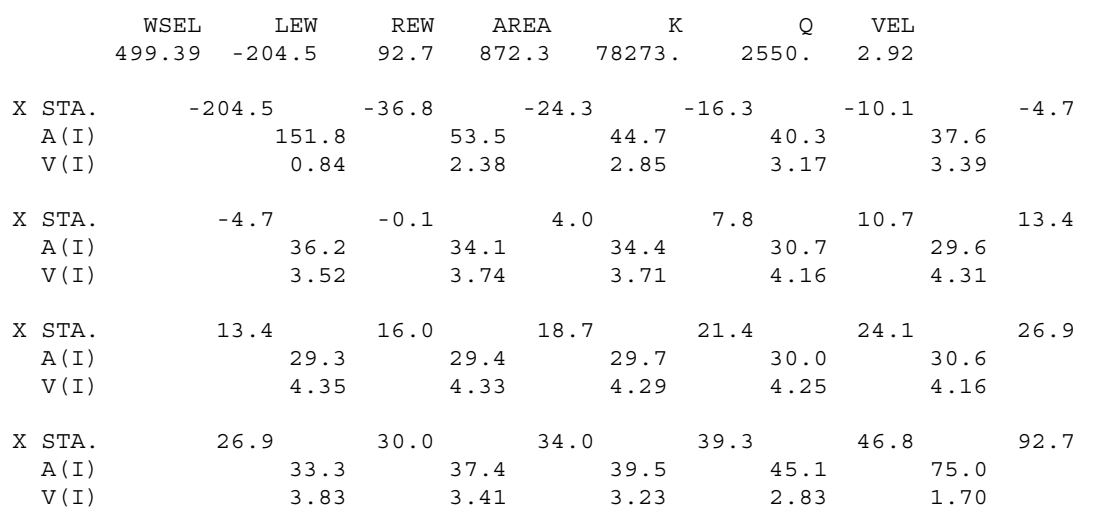


WSPRO OUTPUT FILE (continued)

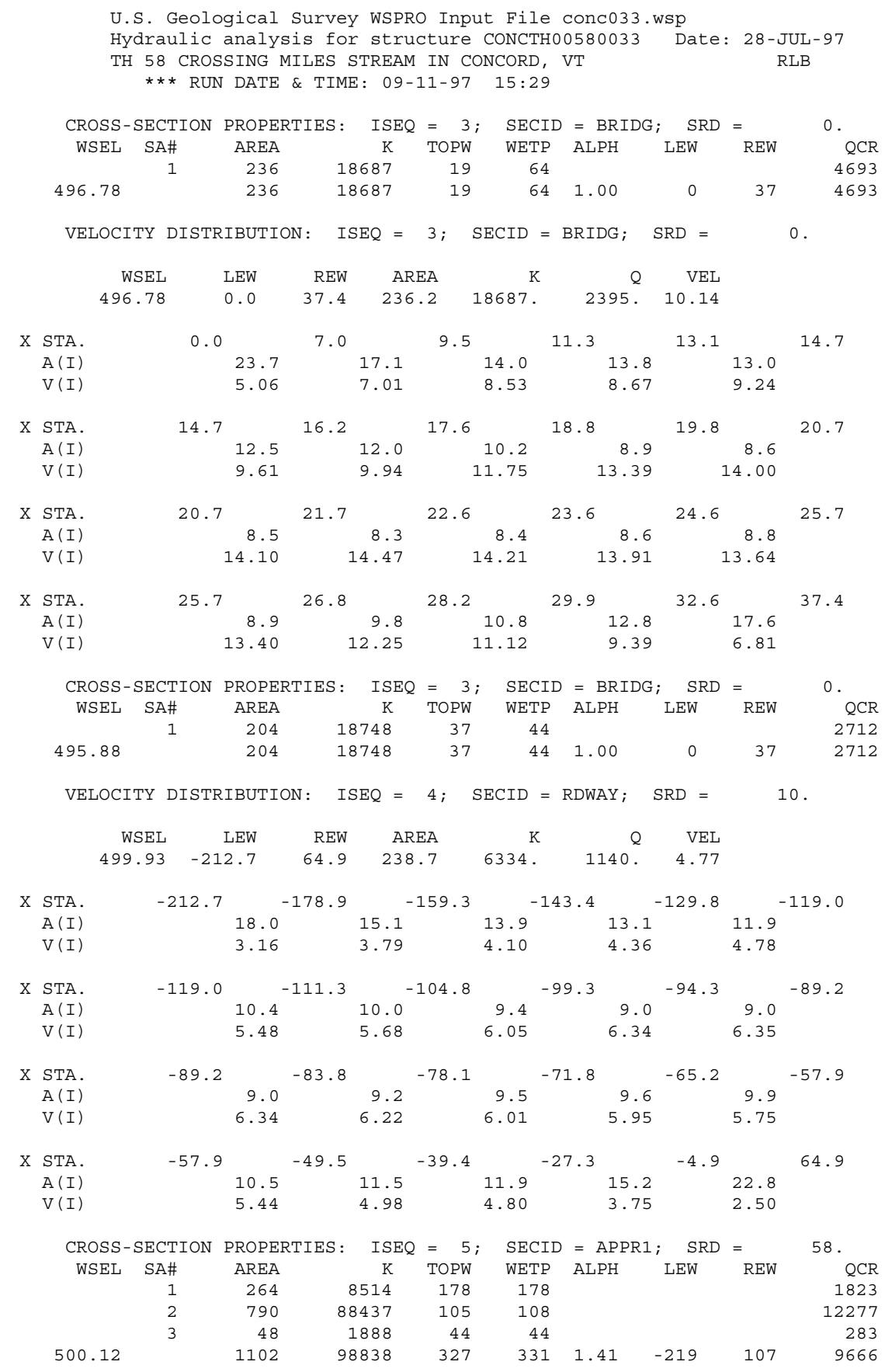

VELOCITY DISTRIBUTION: $\quad$ ISEQ $=5 ; \quad$ SECID $=$ APPR1; $\quad$ SRD $=58$

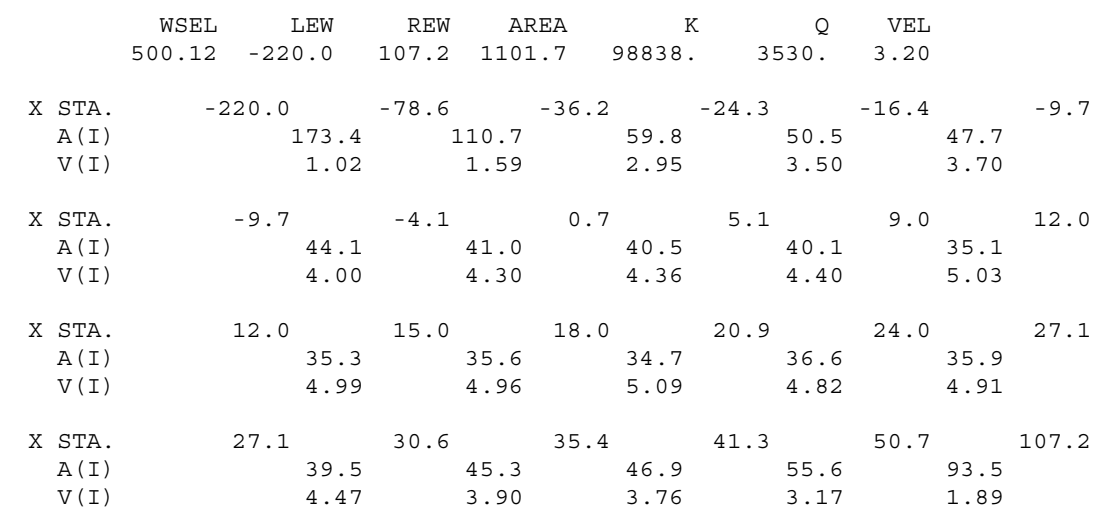


WSPRO OUTPUT FILE (continued)

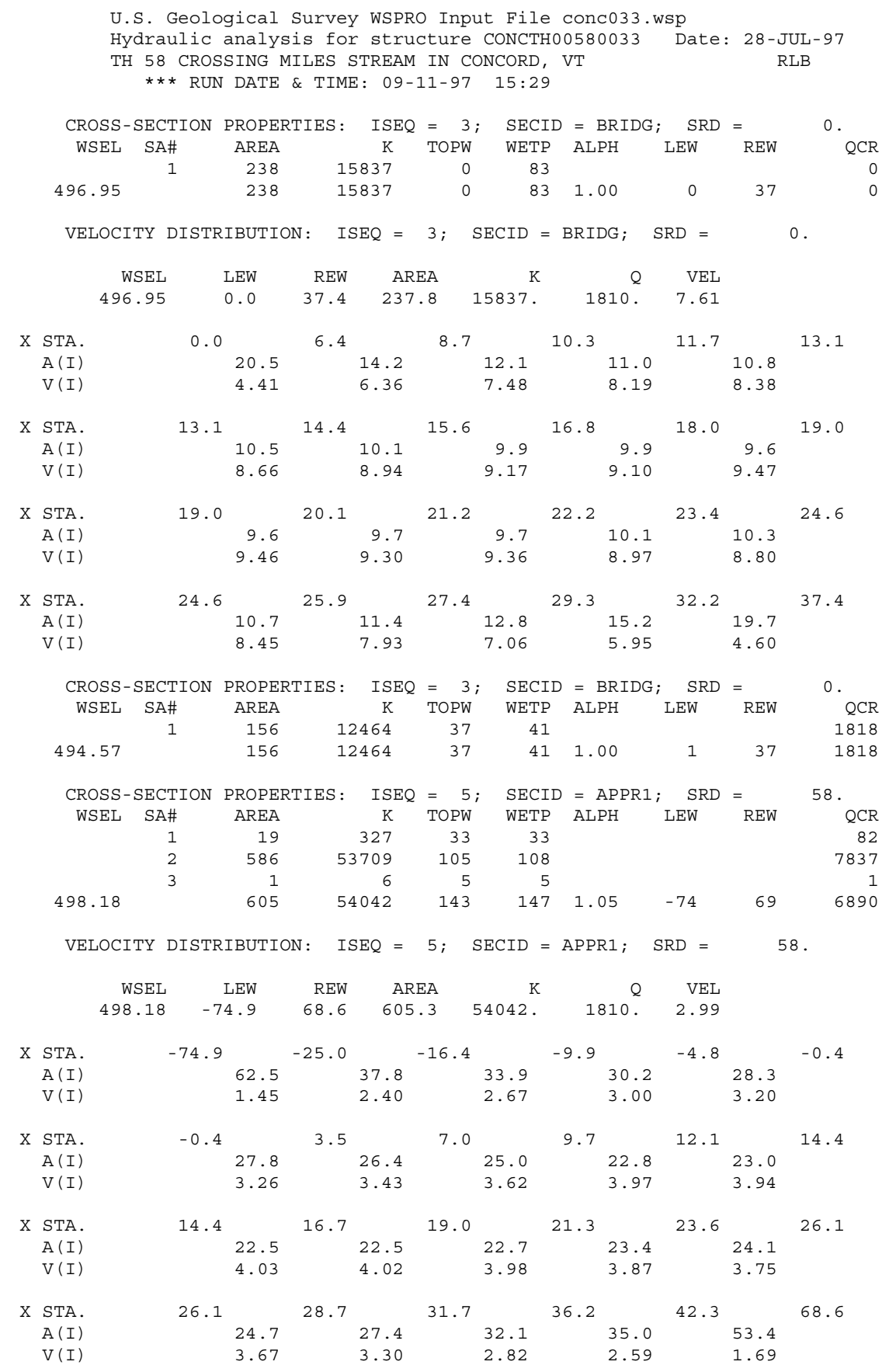


WSPRO OUTPUT FILE (continued)

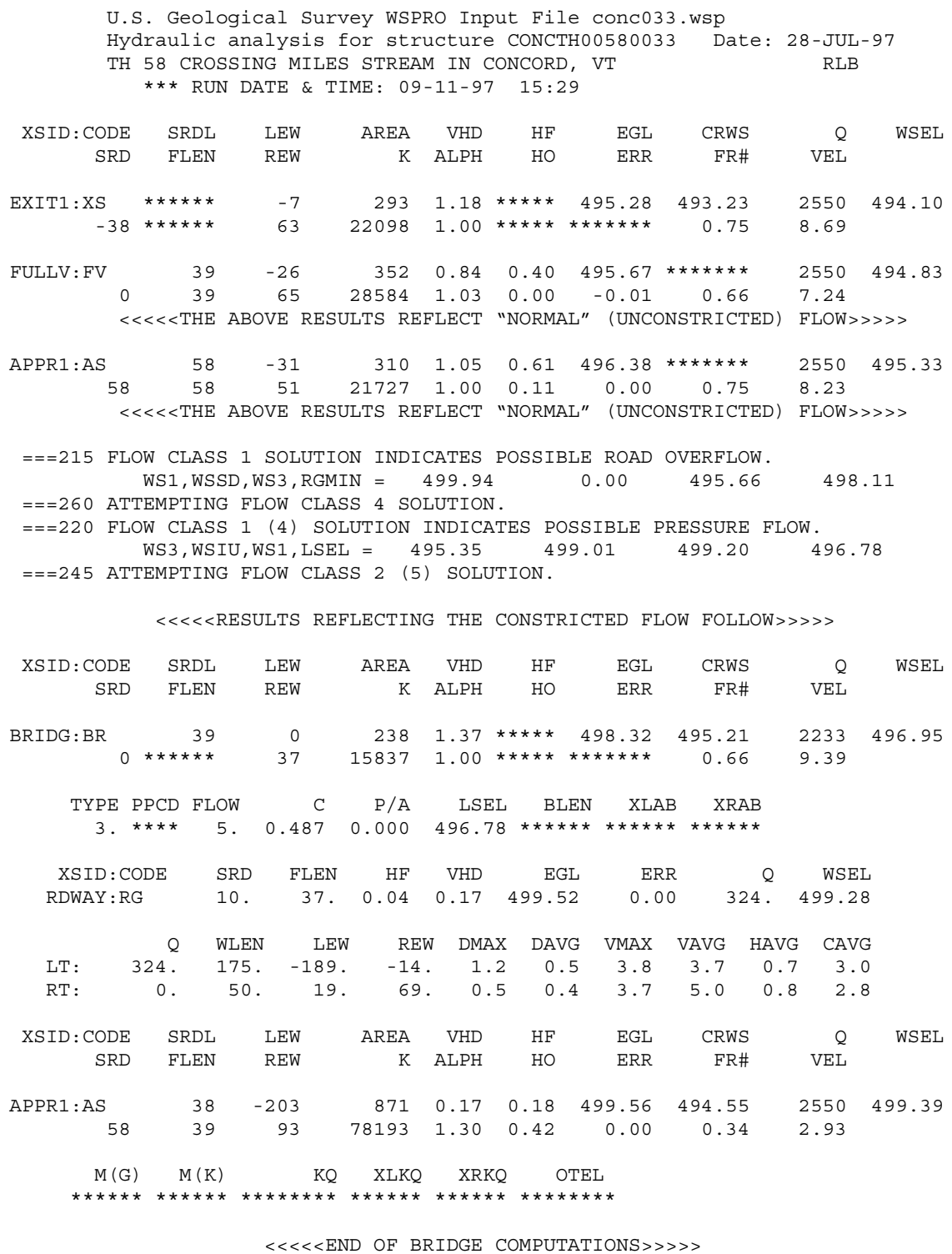

FIRST USER DEFINED TABLE.

\begin{tabular}{|c|c|c|c|c|c|c|c|c|}
\hline XSID: CODE & SRD & LEW & REW & $Q$ & K & AREA & VEL & WSEL \\
\hline EXIT1:XS & -39 & -8 & 63. & 2550 . & 22098 . & 293. & 8.69 & 494.10 \\
\hline FULLV : FV & 0. & -27 & 65. & 2550 . & 28584 . & 352 . & 7.24 & 494.83 \\
\hline BRIDG : BR & 0 . & 0 . & 37. & 2233 . & 15837. & 238. & 9.39 & 496.95 \\
\hline RDWAY : RG & 10. * & 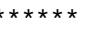 & 324 . & 324. & 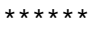 & 0 . & 2.00 & 499.28 \\
\hline APPR I : AS & 58. & -204 & 93. & 2550 . & 78193. & 871. & 2.93 & 499.3 \\
\hline XSID: CODE & XLKQ & XRKQ & & & & & & \\
\hline
\end{tabular}

SECOND USER DEFINED TABLE.

$\begin{array}{lcrrrrrrrr}\text { XSID : CODE } & \text { CRWS } & \text { FR\# } & \text { YMIN } & \text { YMAX } & \text { HF } & \text { HO } & \text { VHD } & \text { EGL } & \text { WSEL } \\ \text { EXIT1:XS } & 493.23 & 0.75 & 488.10 & 510.71 * * * * * * * * * * & 1.18 & 495.28 & 494.10 \\ \text { FULLV :FV } & * * * * * * * * & 0.66 & 488.10 & 510.71 & 0.40 & 0.00 & 0.84 & 495.67 & 494.83 \\ \text { BRIDG:BR } & 495.21 & 0.66 & 487.59 & 496.95 * * * * * * * * * * & 1.37 & 498.32 & 496.95 \\ \text { RDWAY:RG } & * * * * * * * * * * * * * * * & 498.11 & 511.39 & 0.04 * * * * * * & 0.17 & 499.52 & 499.28 \\ \text { APPR1:AS } & 494.55 & 0.34 & 488.26 & 511.13 & 0.18 & 0.42 & 0.17 & 499.56 & 499.39\end{array}$


WSPRO OUTPUT FILE (continued)

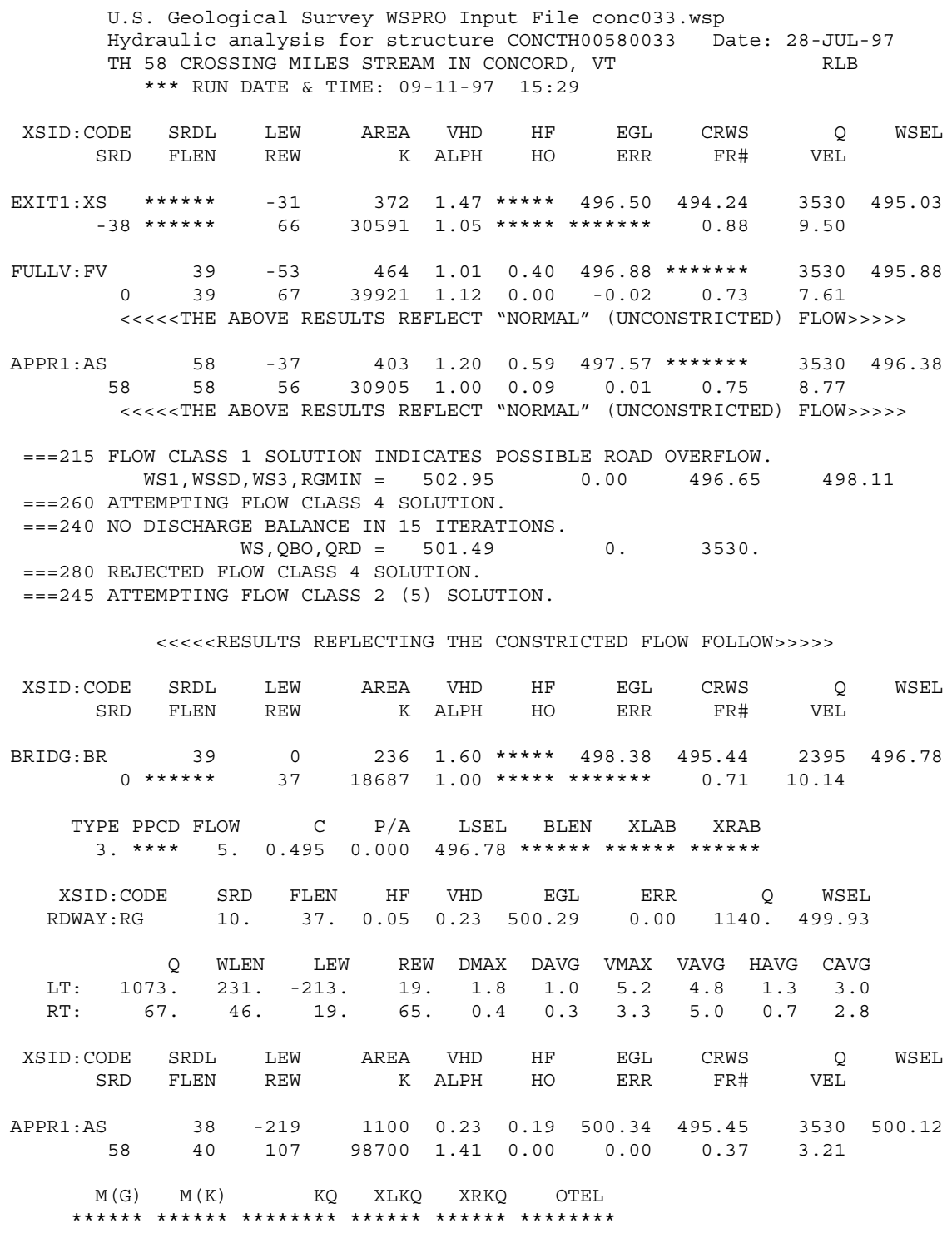

$<<<<$ END OF BRIDGE COMPUTATIONS $>>>>>$

FIRST USER DEFINED TABLE.

\begin{tabular}{|c|c|c|c|c|c|c|c|c|}
\hline XSID : CODE & SRD & LEW & REW & $Q$ & K & AREA & VEL & WSEL \\
\hline EXIT1:XS & -39 & -32 . & 66. & 3530 . & 30591 . & 372 . & 9.50 & 495.03 \\
\hline FULLV: FV & 0 . & -54. & 67. & 3530. & 39921. & 464. & 7.61 & 495.88 \\
\hline BRIDG : BR & 0 . & 0 . & 37. & 2395. & 18687. & 236 . & 10.14 & 496.78 \\
\hline RDWAY : RG & 10. & $\star \star \star \star \star \star *$ & 1073. & 1140. & 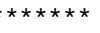 & 0 . & 2.00 & 499.93 \\
\hline APPR1: AS & 58. & -220 & 107. & 3530. & 98700. & 1100. & 3.21 & 500.12 \\
\hline XSID : CODE & XLKQ & XRKQ & & & & & & \\
\hline
\end{tabular}

SECOND USER DEFINED TABLE.

$\begin{array}{lcrrrrrrrr}\text { XSID : CODE } & \text { CRWS } & \text { FR\# } & \text { YMIN } & \text { YMAX } & \text { HF } & \text { HO } & \text { VHD } & \text { EGL } & \text { WSEL } \\ \text { EXIT1:XS } & 494.24 & 0.88 & 488.10 & 510.71 * * * * * * * * * * & 1.47 & 496.50 & 495.03 \\ \text { FULLV:FV } & * * * * * * * * & 0.73 & 488.10 & 510.71 & 0.40 & 0.00 & 1.01 & 496.88 & 495.88 \\ \text { BRIDG:BR } & 495.44 & 0.71 & 487.59 & 496.95 * * * * * * * * * * & 1.60 & 498.38 & 496.78 \\ \text { RDWAY:RG } & * * * * * * * * * * * * * * * & 498.11 & 511.39 & 0.05 * * * * * * & 0.23 & 500.29 & 499.93 \\ \text { APPR1:AS } & 495.45 & 0.37 & 488.26 & 511.13 & 0.19 & 0.00 & 0.23 & 500.34 & 500.12\end{array}$


WSPRO OUTPUT FILE (continued)

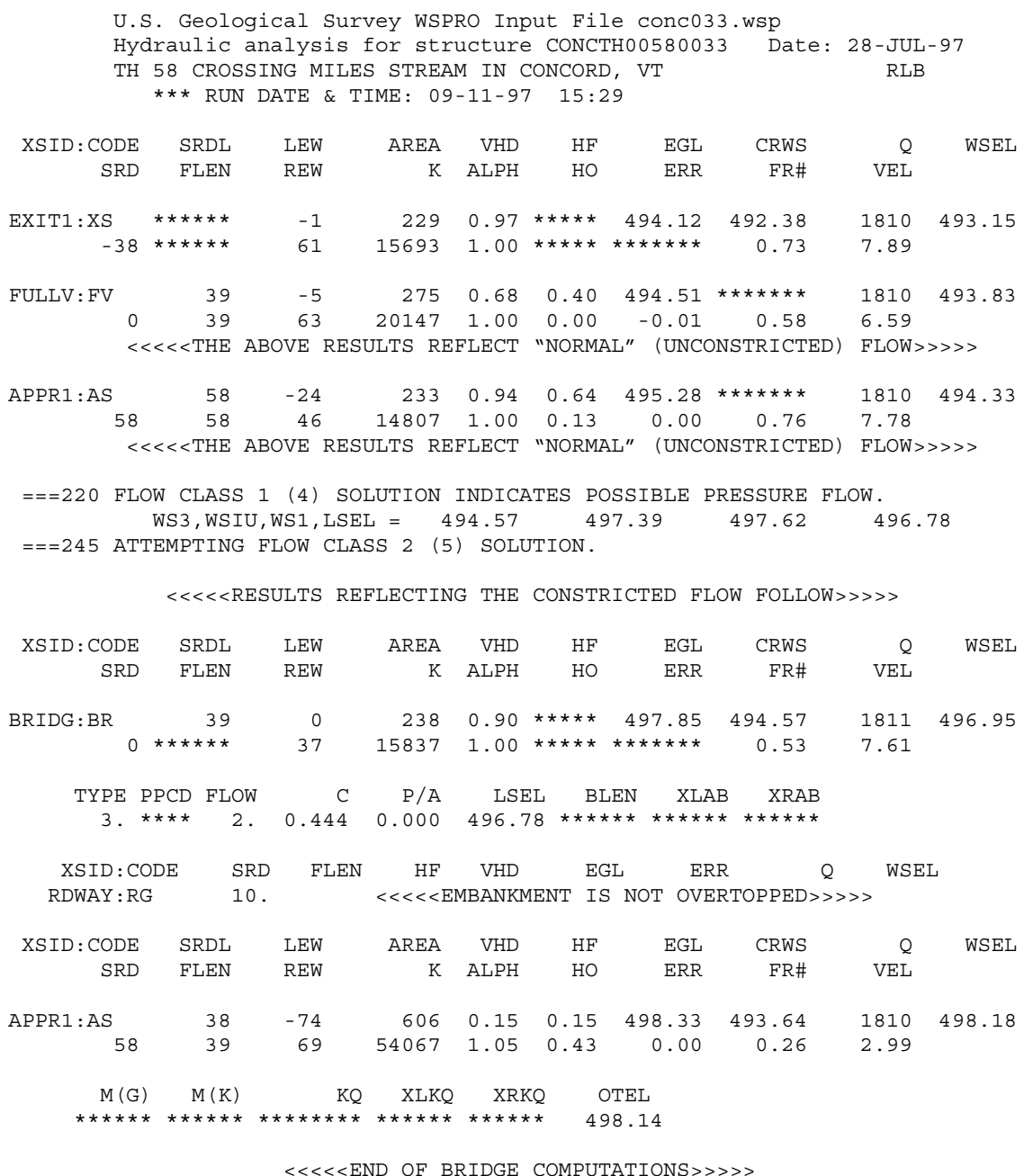

FIRST USER DEFINED TABLE.

\begin{tabular}{|c|c|c|c|c|c|c|c|c|}
\hline XSID : CODE & SRD & LEW & REW & Q & K & AREA & VEL & WSEL \\
\hline EXIT1:XS & -39 & -2 . & 61. & 1810. & 15693. & 229. & 7.89 & 493.15 \\
\hline FULLV : FV & 0. & -6 & 63. & 1810. & 20147 . & 275 . & 6.59 & 493.83 \\
\hline BRIDG : BR & 0 . & 0. & 37. & 1811. & 15837. & 238 . & 7.61 & 496.95 \\
\hline RDWAY : RG & 10.* & $\star \star \star * \star$ & $* * *$ & 0 . & 0 . & 0 . & $2.00 *$ & $* * * * *$ \\
\hline APPR 1 : AS & 58 & -75 & 69. & 1810. & 54067 & 606. & 2.99 & 498.18 \\
\hline XSID: CODE & XLKQ & XRKQ & & & & & & \\
\hline
\end{tabular}

SECOND USER DEFINED TABLE.

\begin{tabular}{|c|c|c|c|c|c|c|c|c|c|}
\hline XSID : CODE & CRWS & FR\# & YMIN & YMAX & $\mathrm{HF}$ & $\mathrm{HO}$ & VHD & EGL & WSEL \\
\hline EXIT1:XS & 492.38 & 0.73 & 488.10 & $510.71 *$ & $k * * \star * * *$ & 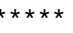 & 0.97 & 494.12 & 493.15 \\
\hline FULLV: FV & 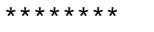 & 0.58 & 488.10 & 510.71 & 0.40 & 0.00 & 0.68 & 494.51 & 493.83 \\
\hline BRIDG : BR & 494.57 & 0.53 & 487.59 & $496.95 *$ & $* * * * * * *$ & 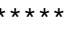 & 0.90 & 497.85 & 496.95 \\
\hline RDWAY : RG & 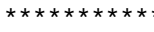 & $\star * \star \star * *$ & 498.11 & $511.39 *$ & $\star * \star * \star * * *$ & $\star \star \star \star \star *$ & 0.15 & $498.29 *$ & $* \star \star \star \star \star * \star *$ \\
\hline APPR1:AS & 493.64 & 0.26 & 488.26 & 511.13 & 0.15 & 0.43 & 0.15 & 498.33 & 498.18 \\
\hline
\end{tabular}




\section{APPENDIX C:}

\section{BED-MATERIAL PARTICLE-SIZE DISTRIBUTION}




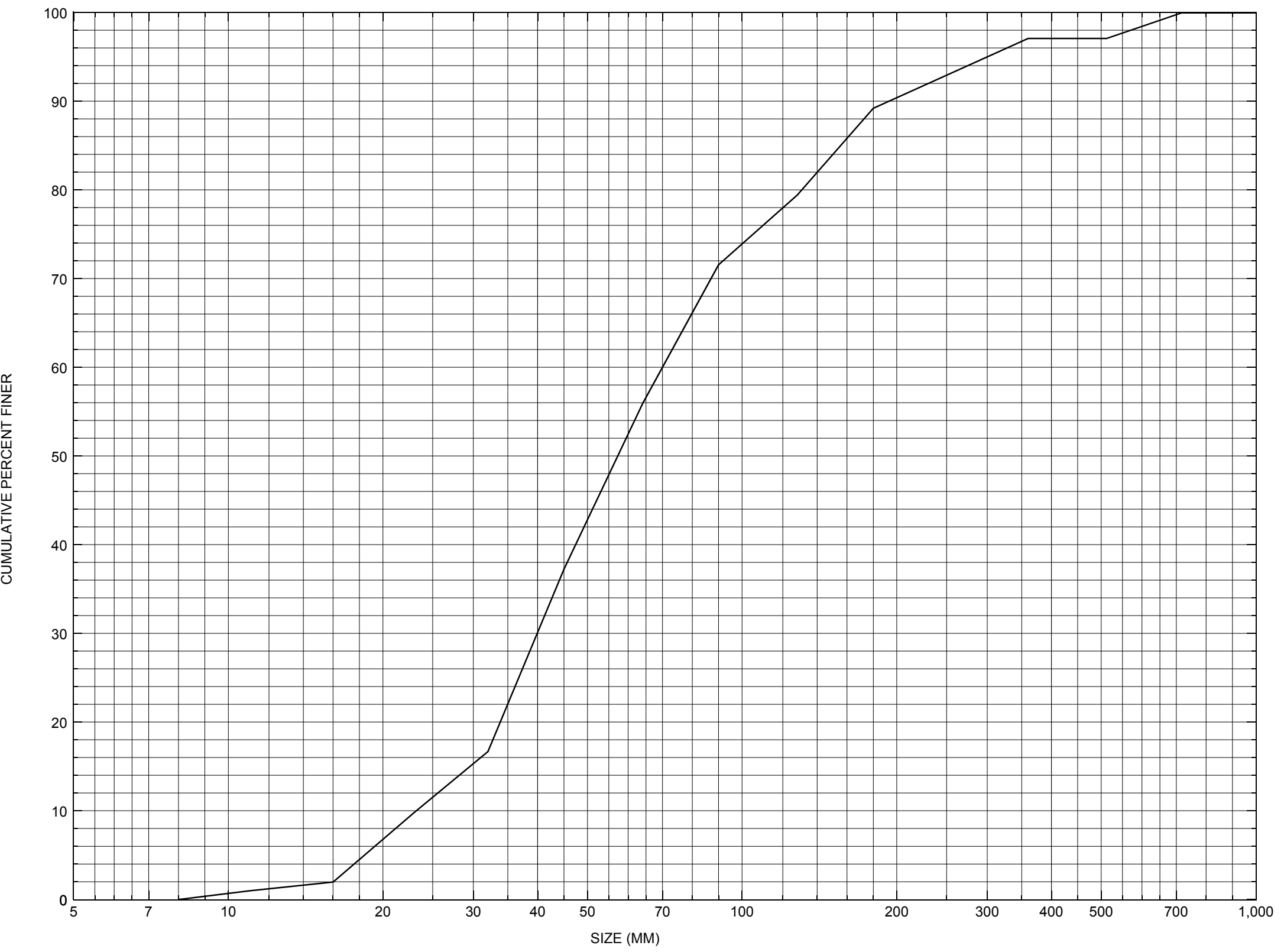

Appendix C. Bed material particle-size distribution for a pebble count in the channel approach of structure CONCTH00580033, in Concord, Vermont. 


\section{APPENDIX D: \\ HISTORICAL DATA FORM}




\section{Structure Number CONCTH00580033}

\section{General Location Descriptive}

Data collected by (First Initial, Full last name) $\mathbf{E}$. BOEHMLER

Date $(M M / D D / Y Y) \_\mathbf{0 3} / \underline{24} / \underline{95}$

Highway District Number (I - 2; nn) $\mathbf{0 7}$

Town (FIPS place code; I - 4; nnnnn) $\mathbf{1 5 2 5 0}$

Waterway (I - 6) MILES STREAM

Route Number $\underline{\text { TH058 }}$

Topographic Map Miles Pond

Latitude (I - 16; nnnn.n) $\mathbf{4 4 2 5 5}$
County (FIPS county code; I - 3; nnn)

Mile marker (I - 11; nnn.nnn) $\mathbf{0 0 0 0 0 0}$

Road Name (I - 7): -

Vicinity (I - 9) 0.1 MI JCT TH $58+$ TH 4

Hydrologic Unit Code: $\mathbf{0 1 0 8 0 1 0 2}$

Longitude (i - 17; nnnnn.n) $\mathbf{7 1 4 5 3}$

\section{Select Federal Inventory Codes}

FHWA Structure Number (I - 8) $\mathbf{1 0 0 5 0 7 0 0 3 3 0 5 0 7}$

Maintenance responsibility $(I-21 ; n n) \_$03 _ Maximum span length $(I-48$; $n n n n) \underline{\mathbf{0 0 3 9}}$

Year built (I - 27; YYYY) 1971

Structure length (I - 49; nnnnnn) $\underline{\mathbf{0 0 0 0 4 4}}$

Average daily traffic, ADT (I - 29; nnnnnn) 000050

Deck Width (I - 52; nn.n) 206

Year of ADT (I - 30; YY) $\mathbf{9 2}$

Channel \& Protection $(I-61 ; n) \underline{\mathbf{5}}$

Opening skew to Roadway $(I-34 ; n n) \quad \mathbf{0 0}$

Waterway adequacy $(I-71 ; n) \underline{6}$

Operational status $(I-41 ; X) \quad \mathbf{A}$

Underwater Inspection Frequency $(I-92 B ; X Y Y) \_\mathbf{N}$

Structure type (I- 43; nnn) $\mathbf{3 0 2}$

Year Reconstructed (I - 106) $\mathbf{0 0 0 0}$

Approach span structure type (I - 44; nnn) $\mathbf{0 0 0}$ Clear span (nnn.n ft) _

Number of spans (I - 45; nnn) $\underline{\mathbf{0 0 1}}$

Vertical clearance from streambed (nnn.n ft) $\underline{\mathbf{0 0 7 . 9}}$

Number of approach spans (I - 46; nnnn) $\mathbf{0 0 0 0}$ Waterway of full opening $\left(n n n . n \mathrm{ft}^{2}\right)$

Comments:

The structural inspection report of $8 / 15 / 94$ indicates the structure is a steel stringer type bridge with a concrete deck. The abutment walls are concrete. Approximately a ten foot section of the left abutment footing is reported undermined by 2 to 3 feet horizontally and 2 to 5 inches vertically . "Boulder stone fill" is placed in front of each abutment and around the ends. There are some boulders noted on the banks upand downstream. While the left abutment is undermined, the report does not indicate any settling evident. Channel scour, bank erosion, and debris accumulation were not assessed in the report. The type of foundation recorded for the substructure at this site is an unknown foundation. 


\section{Bridge Hydrologic Data}

Is there hydrologic data available? $\underline{\mathbf{N}}$ if No, type ctrl-n $h \quad$ VTAOT Drainage area $\left(m i^{2}\right)$ : -

Terrain character:

Stream character \& type: -

Streambed material:

Discharge Data (cfs):

$$
\begin{aligned}
& Q_{2.33}- \\
& Q_{50}-
\end{aligned}
$$

Record flood date $(M M / D D / Y Y)$ :

Estimated Discharge (cfs): Ice conditions (Heavy, Moderate, Light) : -

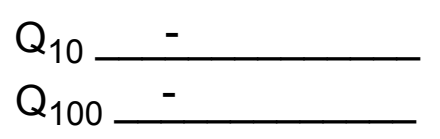

$$
\begin{aligned}
& Q_{25}- \\
& Q_{500}-
\end{aligned}
$$

Water surface elevation $(f t):-$

The stage increases to maximum highwater elevation (Rapidly, Not rapidly):

The stream response is (Flashy, Not flashy):

Describe any significant site conditions upstream or downstream that may influence the stream's stage: -

Watershed storage area (in percent): _ _ \%

The watershed storage area is: - (1-mainly at the headwaters; 2- uniformly distributed; 3-immediatly upstream oi the site)

Water Surface Elevation Estimates for Existing Structure:

\begin{tabular}{|l|l|l|l|l|l|}
\hline Peak discharge frequency & $Q_{2.33}$ & $Q_{10}$ & $Q_{25}$ & $Q_{50}$ & $Q_{100}$ \\
Water surface elevation (ft)) & - & - & - & - & - \\
Velocity (ft/sec) & - & - & - & - & - \\
\hline
\end{tabular}

Long term stream bed changes: -

Is the roadway overtopped below the $\mathrm{Q}_{100}$ ? (Yes, No, Unknown): $\mathbf{U}$ Frequency: Relief Elevation (ft): Discharge over roadway at $Q_{100}\left(f^{3} / \mathrm{sec}\right)$ :

Are there other structures nearby? (Yes, No, Unknown): $\underline{\mathbf{U}}$ Upstream distance (miles): Town: If No or Unknown, type ctrl-n os Highway No. : Structure No. : Year Built:

Clear span (ft): Clear Height $(f t)$ : Full Waterway $\left(f^{2}\right)$ : 
Downstream distance (miles): Town: Year Built:

Highway No. : Structure No. : Structure Type:

Clear span (ft): Clear Height $(f t)$ : Full Waterway $\left(f^{2}\right)$ : -

Comments:

\section{USGS Watershed Data}

Watershed Hydrographic Data

Drainage area $(D A) \stackrel{17.861}{\mathrm{mi}^{2}}$

Watershed storage (ST) $\quad \mathbf{2 . 8 9}$

Bridge site elevation $\mathbf{8 6 5} \mathrm{ft}$

Main channel length $\mathbf{7 . 5 6 7}$ mi

$10 \%$ channel length elevation $\mathbf{9 1 0}$

Lake/pond/swamp area

.517 $\mathrm{mi}^{2}$ $\%$

Main channel slope $(S)$
(S)

68.02 $\mathrm{ft} / \mathrm{mi}$

Headwater elevation

1560 $\mathrm{ft}$

Watershed Precipitation Data

Average site precipitation in

Average headwater precipitation in

Maximum 2yr-24hr precipitation event $(124,2)$ in

Average seasonal snowfall (Sn) $\mathrm{ft}$ 


\section{Bridge Plan Data}

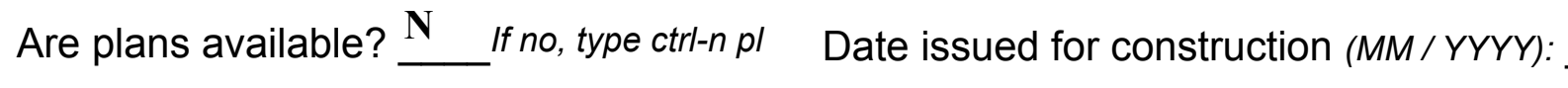

Project Number

Minimum channel bed elevation:

Low superstructure elevation: USLAB DSLAB USRAB DSRAB Benchmark location description:

NO BENCHMARK INFORMATION

Reference Point (MSL, Arbitrary, Other): Datum (NAD27, NAD83, Other):

Foundation Type: 4

If 1 : Footing Thickness

If 2: Pile Type:

If 3: Footing bottom elevation:

Is boring information available? $\mathbf{N}$

Foundation Material Type: $\mathbf{3}$

(1-Spreadfooting; 2-Pile; 3- Gravity; 4-Unknown)

Footing bottom elevation: -

Briefly describe material at foundation bottom elevation or around piles:

NO FOUNDATION MATERIAL INFORMATION

Comments:

NO PLANS. 


\section{Cross-sectional Data}

Is cross-sectional data available? $\underline{\mathbf{N}}$ If no, type ctrl-n xs

Source (FEMA, VTAOT, Other)? -

Comments: NO CROSS SECTION INFORMATION

\begin{tabular}{|l|l|l|l|l|l|l|l|l|l|l|l|}
\hline Station & - & - & - & - & - & - & - & - & - & - & - \\
\hline Feature & - & - & - & - & - & - & - & - & - & - & - \\
\hline $\begin{array}{l}\text { Low chord } \\
\text { elevation }\end{array}$ & - & - & - & - & - & - & - & - & - & - & - \\
\hline $\begin{array}{l}\text { Bed } \\
\text { elevation }\end{array}$ & - & - & - & - & - & - & - & - & - & - & - \\
\hline $\begin{array}{l}\text { Low chord- } \\
\text { bed }\end{array}$ & - & - & - & - & - & - & - & - & - & - & - \\
\hline Station & - & - & - & - & - & - & - & - & - & - & - \\
\hline Feature & - & - & - & - & - & - & - & - & - & - & - \\
\hline $\begin{array}{l}\text { Low chord } \\
\text { elevation }\end{array}$ & - & - & - & - & - & - & - & - & - & - & - \\
\hline $\begin{array}{l}\text { Bed } \\
\text { elevation }\end{array}$ & - & - & - & - & - & - & - & - & - & - & - \\
\hline $\begin{array}{l}\text { Low chord- } \\
\text { bed }\end{array}$ & - & - & - & - & - & - & - & - & - & - & - \\
\hline
\end{tabular}

Source (FEMA, VTAOT, Other)?

Comments: NO CROSS SECTION INFORMATION

\begin{tabular}{|l|l|l|l|l|l|l|l|l|l|l|l|}
\hline Station & - & - & - & - & - & - & - & - & - & - & - \\
\hline Feature & - & - & - & - & - & - & - & - & - & - & - \\
\hline $\begin{array}{l}\text { Low chord } \\
\text { elevation }\end{array}$ & - & - & - & - & - & - & - & - & - & - & - \\
\hline $\begin{array}{l}\text { Bed } \\
\text { elevation }\end{array}$ & - & - & - & - & - & - & - & - & - & - & - \\
\hline $\begin{array}{l}\text { Low chord- } \\
\text { bed }\end{array}$ & - & - & - & - & - & - & - & - & - & - & - \\
\hline Station & - & - & - & - & - & - & - & - & - & - & - \\
\hline Feature & - & - & - & - & - & - & - & - & - & - & - \\
\hline $\begin{array}{l}\text { Low chord } \\
\text { elevation }\end{array}$ & - & - & - & - & - & - & - & - & - & - & - \\
\hline $\begin{array}{l}\text { Bed } \\
\text { elevation }\end{array}$ & - & - & - & - & - & - & - & - & - & - & - \\
\hline $\begin{array}{l}\text { Low chord- } \\
\text { bed }\end{array}$ & - & - & - & - & - & - & - & - & - & - & - \\
\hline
\end{tabular}




\section{APPENDIX E: \\ LEVEL I DATA FORM}


U. S. Geological Survey

Bridge Field Data Collection and Processing Form

Qa/Qc Check by: EW

Date: $\underline{\mathbf{0 2} / \mathbf{0 5} / \mathbf{9 6}}$

\section{Structure Number}

CONCTH00580033

\section{A. General Location Descriptive}

1. Data collected by (First Initial, Full last name) M. IVANOFF

Date $(M M / D D / Y Y) \mathbf{0 8} / 15 / 1995$

2. Highway District Number 7

County ESSEX (009)

Waterway $(l$ - 6) MILES STREAM

Route Number $\mathbf{T H 0 5 8}$

3. Descriptive comments:

Located 0.1 miles from the junction of TH 58 and TH 4.
Mile marker $\mathbf{0}$

Town CONCORD (15250)

Road Name -

Hydrologic Unit Code: $\mathbf{0 1 0 8 0 1 0 2}$

\section{B. Bridge Deck Observations}
4. Surface cover... LBUS 5
RBUS 4
LBDS 5
RBDS 6
Overall 5

(2b us,ds,lb,rb: 1- Urban; 2- Suburban; 3- Row crops; 4- Pasture; 5- Shrub- and brushland; 6- Forest; 7- Wetland)
5. Ambient water surface... US 1
UB 1
DS 2
(1- pool; 2- riffle)

6. Bridge structure type 1 (1- single span; 2- multiple span; 3- single arch; 4- multiple arch; 5-cylindrical culvert; 6- box culvert; or 7- other)
7. Bridge length 44
(feet)
Span length $\underline{39}$
(feet)
Bridge width 20.6 (feet)

\section{Road approach to bridge:}
8. LB 1
RB 2
( 0 even, 1- lower, 2- higher)
9. LB_2
RB $\underline{2}$
(1- Paved, 2- Not paved)

10. Embankment slope (run / rise in feet / foot)

US left

US right

\begin{tabular}{|c|c|c|c|}
\hline \multicolumn{2}{|c|}{ Protection } & \multirow{2}{*}{ 13.Erosion } & 14.Severity \\
\hline 11.Type & 12.Cond. & $\mathbf{0}$ & $\mathbf{0}$ \\
\hline $\mathbf{0}$ & - & $\mathbf{0}$ & $\mathbf{0}$ \\
\hline $\mathbf{0}$ & - & $\mathbf{0}$ & $\mathbf{0}$ \\
\hline $\mathbf{0}$ & - & $\mathbf{0}$ & $\mathbf{0}$ \\
\hline $\mathbf{0}$ & - & $\mathbf{0}$ & $\mathbf{0}$ \\
\hline
\end{tabular}

Bank protection types: 0- none; 1- < 12 inches;

2- < 36 inches; 3- < 48 inches;

4- < 60 inches; 5- wall / artificial levee

Bank protection conditions: 1- good; 2- slumped;

3- eroded; 4- failed

Erosion: 0 - none; 1- channel erosion; 2 -

road wash; 3- both; 4- other

Erosion Severity: 0 - none; 1- slight; 2- moderate; 3- severe

\section{Channel approach to bridge (BF):}

15. Angle of approach: $\mathbf{1 0}$

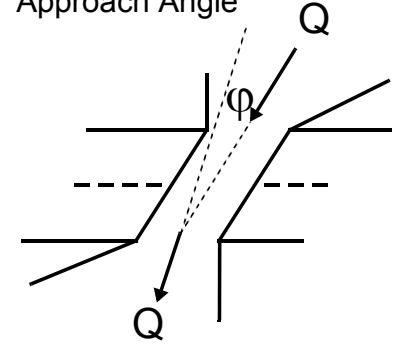

17. Channel impact zone 1 :

Where? LB $(L B, R B)$

Range? 40

feet $\underline{\text { US }}$

Channel impact zone 2:

Where? LB $(L B, R B)$

Range? $\underline{40}$ feet $\underline{\text { DS }}$

Impact Severity: 0- none to very slight; 1- Slight; 2- Moderate; 3- Severe
16. Bridge skew: $\mathbf{2 0}$

Bridge Skew Angle

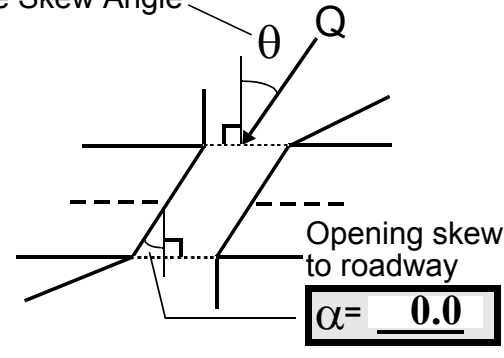

\section{Exist? $\mathbf{Y}(Y$ or $N)$}

Severity 0

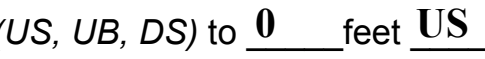

Exist? $\mathbf{Y}(Y$ or $N)$

Severity $\underline{0}$

$U B, D S)$ to $\underline{\mathbf{6 0}}$ feet $\underline{\mathbf{D S}}$ 
18. Bridge Type: $\mathbf{1 b}$

1a- Vertical abutments with wingwalls

$1 \mathrm{~b}$ - Vertical abutments without wingwalls

2- Vertical abutments and wingwalls, sloping embankment Wingwalls parallel to abut. face

3- Spill through abutments

4- Sloping embankment, vertical wingwalls and abutments

Wingwall angle less than $90^{\circ}$.

19. Bridge Deck Comments (surface cover variations, measured bridge and span lengths, bridge type variations, approach overflow width, etc.)

Values reported in \#7 are from the VTAOT files. Measured bridge dimensions are: bridge length $=44 \mathrm{ft}$, bridge span $=38 \mathrm{ft}$, and bridge width $=20.3 \mathrm{ft}$.

\#4: The right bank vegetation is the backyard of a residential area with some row crops (corn) and cut grass, also some trees along the bank.

\section{Upstream Channel Assessment}

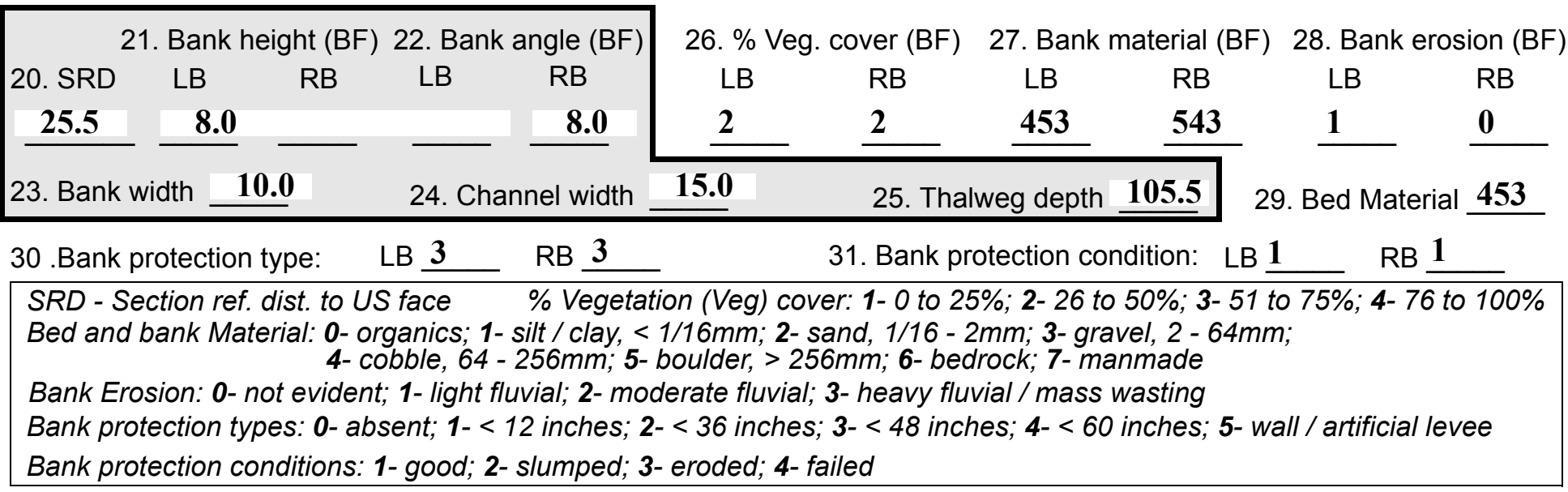

32. Comments (bank material variation, minor inflows, protection extent, etc.):

\#30: On the left bank, the placed protection extends 15 feet US. On the right bank the placed protection extends 160 feet US. 
36. Point bar extent: $\underline{\mathbf{1 1 5}}$ feet $\underline{\mathrm{US}}$ (US, UB) to $\underline{\mathbf{1 7 0}}$ feet $\underline{\mathrm{US}}$ (US, UB, DS) positioned $\underline{\mathbf{0}} \%$ LB to 30 \%RB

37. Material: 32

38. Point or side bar comments (Circle Point or Side; Note additional bars, material variation, status, etc.):

This point bar is along the left bank and consists of gravel and sand.

39. Is a cut-bank present? $\mathbf{Y}$ ( $Y$ or if $N$ type ctrl-n $c b)$

41. Mid-bank distance: $\mathbf{8 0}$

43. Bank damage: 1

42. Cut bank extent: 35
40. Where? $\underline{\mathbf{L B}}$ (LB or RB) feet $\underline{\mathbf{U S}}$ (US, UB) to $\underline{\mathbf{1 1 5}}$ feet $\underline{\mathbf{U S}}$ (US, UB, DS)

44. Cut bank comments (eg. additional cut banks, protection condition, etc.):

In this area, the bank is steepend and there are exposed roots.

45. Is channel scour present? $\mathbf{N}$ (Yor if $N$ type ctrl-n cs) 46. Mid-scour distance: -

47. Scour dimensions: Length - _ Width _ _ Depth : ___ Position - _ \% $\%$ LB to _ $\%$ RB

48. Scour comments (eg. additional scour areas, local scouring process, etc.):

NO CHANNEL SCOUR

Average thalweg depth is 2 feet upstream up to 2.5 feet near the point bar.

49. Are there major confluences? $\mathbf{N}$

51. Confluence 1: Distance -

Confluence 2: Distance -

NO MAJOR CONFLUENCES
( $Y$ or if $N$ type ctrl-n $m c)$

52. Enters on -

Enters on ( $L B$ or $R B)$ ( $L B$ or $R B)$
50. How many? -

53. Type(1- perennial; 2- ephemeral)

Type (1-perennial; 2- ephemeral)

\section{Under Bridge Channel Assessment}

55. Channel restraint (BF)? LB 2

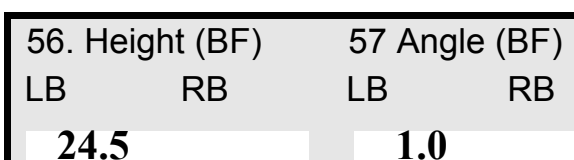

58. Bank width (BF) -

(1- natural bank; 2- abutment; 3- artificial levee)

Bed and bank Material: 0- organics; 1- silt / clay, < 1/16mm; 2- sand, 1/16 - 2mm; 3- gravel, 2 - 64mm; 4- cobble, 64 - 256mm; 5- boulder, > 256mm; 6- bedrock; 7- manmade

Bank Erosion: 0- not evident; 1- light fluvial; 2- moderate fluvial; 3- heavy fluvial / mass wasting

64. Comments (bank material variation, minor inflows, protection extent, etc.):

453 
65. Debris and Ice Is there debris accumulation?

(Yor $N)$ 66. Where? $\underline{Y}$

(1- Upstream; 2- At bridge; 3- Both)

67. Debris Potential 1 (1-Low; 2-Moderate; 3- High)

68. Capture Efficiency 1

(1-Low; 2- Moderate; 3- High)

69. Is there evidence of ice build-up? 2

Ice Blockage Potential $\mathbf{N}$

(1-Low; 2-Moderate; 3- High)

70. Debris and Ice Comments:

1

There are very few trees along the banks in this residential area.

\#68: The capture efficiency is moderate due to the constricted opening from boulder stone fill at the base of the abutments.

\begin{tabular}{|l|c|c|c|c|c|c|c|c|}
\hline Abutments & $\begin{array}{c}\text { 71. Attack } \\
\angle \text { (BF) }\end{array}$ & $\begin{array}{c}72 \text {. Slope } \angle \\
\text { (Qmax) }\end{array}$ & $\begin{array}{c}\text { 73. Toe } \\
\text { loc. (BF) }\end{array}$ & $\begin{array}{c}\text { 74. Scour } \\
\text { Condition }\end{array}$ & $\begin{array}{c}75 . \text { Scour } \\
\text { depth }\end{array}$ & $\begin{array}{c}\text { 76. Exposure } \\
\text { depth }\end{array}$ & 77. Material & 78. Length \\
\hline LABUT & & $\mathbf{1 0}$ & $\mathbf{9 0}$ & $\mathbf{2}$ & $\mathbf{3}$ & $\mathbf{0 . 5}$ & $\mathbf{0}$ & $\mathbf{9 0 . 0}$ \\
\hline RABUT & $\mathbf{1}$ & $\mathbf{0}$ & $\mathbf{9 0}$ & & & $\mathbf{2}$ & $\mathbf{0}$ & $\mathbf{3 7 . 5}$ \\
\hline
\end{tabular}

Pushed: $L B$ or RB

Toe Location (Loc.): 0- even, 1- set back, 2- protrudes

Scour cond.: 0- not evident; 1- evident (comment); 2- footing exposed; 3-undermined footing; 4- piling exposed; 5- settled; 6- failed

Materials: 1- Concrete; 2- Stone masonry or drywall; 3- steel or metal; 4- wood

79. Abutment comments (eg. undermined penetration, unusual scour processes, debris, etc.):

-

1

\#76: The left abutment is undermined a depth of 0.5 feet along 10 feet of length at the midwall. Stone fill sits 0.5 feet from the wall into the stream.

80. Wingwalls:

Exist? Material? Scour Scour Exposure $\begin{aligned} & 81 . \\ & \text { Angle? Length? }\end{aligned}$ Condition? depth? depth?

USLWW:

37.5

USRWW: $\mathbf{N}$

DSLWW: -

DSRWW: -

Wingwall materials: 1- Concrete; 2- Stone masonry or drywall; 3- steel or metal; 4- wood

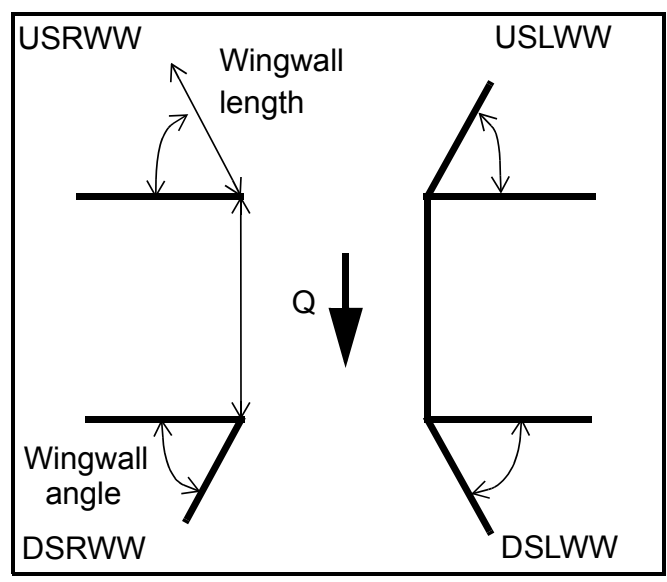

82. Bank / Bridge Protection:

\begin{tabular}{|l|l|l|l|l|l|l|l|c|}
\hline Location & USLWW & USRWW & LABUT & RABUT & LB & RB & DSLWW & DSRWW \\
\hline Type & - & - & $\mathbf{N}$ & - & - & - & $\mathbf{1}$ & $\mathbf{1}$ \\
\hline Condition & $\mathbf{N}$ & - & - & - & - & - & $\mathbf{1}$ & $\mathbf{1}$ \\
\hline Extent & - & - & - & - & - & $\mathbf{3}$ & $\mathbf{3}$ & - \\
\hline
\end{tabular}

Bank / Bridge protection types: 0- absent; 1- < 12 inches; 2- < 36 inches; 3- < 48 inches; 4- < 60 inches; 
83. Wingwall and protection comments (eg. undermined penetration, unusual scour processes, etc.):

-
-
-
-
-
-
-
-
-

\section{Piers:}

84. Are there piers? Th (Y or if $N$ type ctrl-n pr)

\begin{tabular}{|l|l|l|l|l|l|l|l|}
\hline \multirow{2}{*}{$\begin{array}{l}85 . \\
\text { Pier no. }\end{array}$} & \multicolumn{3}{|c|}{ width (w) feet } & \multicolumn{3}{c|}{ elevation (e) feet } \\
\cline { 2 - 9 } & w1 & w2 & w3 & e@w1 & e@w2 & e@w3 \\
\hline Pier 1 & - & - & - & - & - & - \\
\hline Pier 2 & - & - & - & - & - & - \\
\hline Pier 3 & - & - & - & - & - & - \\
\hline Pier 4 & - & - & - & - & - & - \\
\hline
\end{tabular}

\begin{tabular}{|l|l|l|l|l|}
\hline Level 1 Pier Descr. & \multicolumn{1}{|c|}{1} & 2 & 3 & \multicolumn{1}{|c|}{} \\
\hline 86. Location (BF) & e abut- & & - & - \\
\hline 87. Type & ment & & - & - \\
\hline 88. Material & s are & & - & - \\
\hline 89. Shape & pro- & & - & - \\
\hline 90. Inclined? & tecte & & - & - \\
\hline 91. Attack $\angle$ (BF) & d by & & - & - \\
\hline 92. Pushed & boul- & & - & - \\
\hline 93. Length (feet) & - & - & - & - \\
\hline 94. \# of piles & der & N & - & - \\
\hline 95. Cross-members & fill. & - & - & - \\
\hline 96. Scour Condition & & - & - & - \\
\hline 97. Scour depth & & - & - & - \\
\hline 98. Exposure depth & & - & - & - \\
\hline
\end{tabular}

LFP, LTB, LB, MCL, MCM, MCR, RB, RTB, RFP

1- Solid pier, 2- column, 3- bent

1-Wood; 2- concrete; 3- metal; 4- stone

1- Round; 2- Square; 3- Pointed

Y-yes; $N-$ no

$L B$ or $R B$

0- none; 1- laterals; 2- diagonals; 3- both

0- not evident; 1- evident (comment);

2- footing exposed; 3- piling exposed;

4- undermined footing; 5- settled; 6 - failed 
99. Pier comments (eg. undermined penetration, protection and protection extent, unusual scour processes, etc.):

-
-
-
-
-
-
-
-
-
-

100.

\section{E. Downstream Channel Assessment}

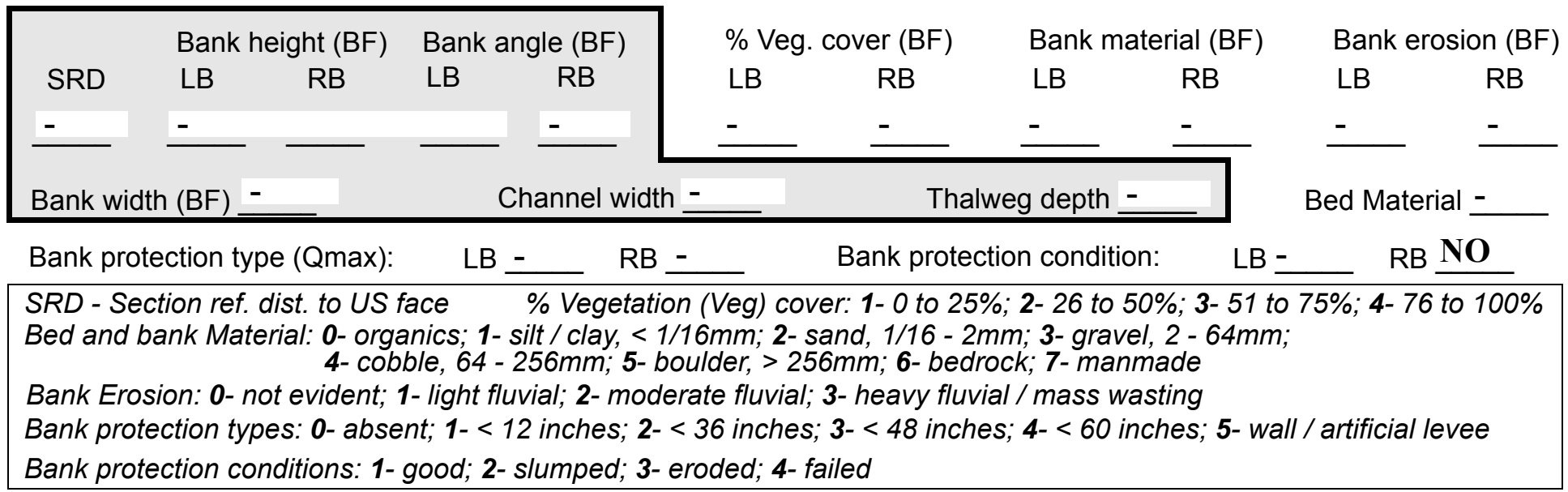

Comments (eg. bank material variation, minor inflows, protection extent, etc.):

\section{PIERS}

$\mathbf{0}$

101. Is a drop structure present? $\mathbf{0}$ ( $Y$ or $N$, if $N$ type ctrl-n ds) 102. Distance: ___ feet 103. Drop: -_ feet 104. Structure material: $\mathbf{5 4 3}$ (1- steel sheet pile; 2- wood pile; 3- concrete; 4- other) 105. Drop structure comments (eg. downstream scour depth):

3

3

1

1

The placed bank protection extends 20 feet DS on the right and 80 feet DS on the left. 

feet (US, UB, DS) to feet (US, UB, DS) positioned $\%$ LB to $\% \mathrm{RB}$

Material:

Point or side bar comments (Circle Point or Side; note additional bars, material variation, status, etc.):

$\mathbf{N}$

Is a cut-bank present? - (Y or if $N$ type ctrl-n cb) Where? NO (LB or RB) Mid-bank distance: DR Cut bank extent: $\underline{\mathbf{O P}}$ feet $\underline{\mathbf{S T}}$ (US, UB, DS) to $\underline{\mathbf{R U C}}$ feet $\underline{\mathbf{T U}}$ (US, UB, DS)

Bank damage: $\underline{\mathbf{R E}}$ (1-eroded and/or creep; 2- slip failure; 3- block failure)

Cut bank comments (eg. additional cut banks, protection condition, etc.):

Is channel scour present? ( $Y$ or if $N$ type ctrl-n cs)

Mid-scour distance: $\underline{\mathbf{N}}$

Scour dimensions: Length Width Depth: -

Positioned $\%$ LB to $\%$ RB Scour comments (eg. additional scour areas, local scouring process, etc.):

$-$

$-$

Are there major confluences? $\mathbf{N}$ (Yor if $N$ type ctrl-n $m c$ ) Confluence 1: Distance POI Confluence 2: Distance RS Enters on $\mathbf{N T}$ ( $L B$ or $R B)$ Enters on $\underline{\mathbf{A}}$ (LB or $R B)$
How many?

Type BA (1- perennial; 2- ephemeral)

Type boul (1- perennial; 2- ephemeral)

Confluence comments (eg. confluence name):

der riffle begins 45 feet $D S$ from the bridge.

\section{F. Geomorphic Channel Assessment}

107. Stage of reach evolution
1- Constructed

2- Stable

3- Aggraded

4- Degraded

5- Laterally unstable

6- Vertically and laterally unstable 
108. Evolution comments (Channel evolution not considering bridge effects; See HEC-20, Figure 1 for geomorphic descriptors): $\mathbf{N}$

$-$

$-$

$-$

$-$

$-$

$-$

NO CUT BANKS

$\mathbf{N}$ 


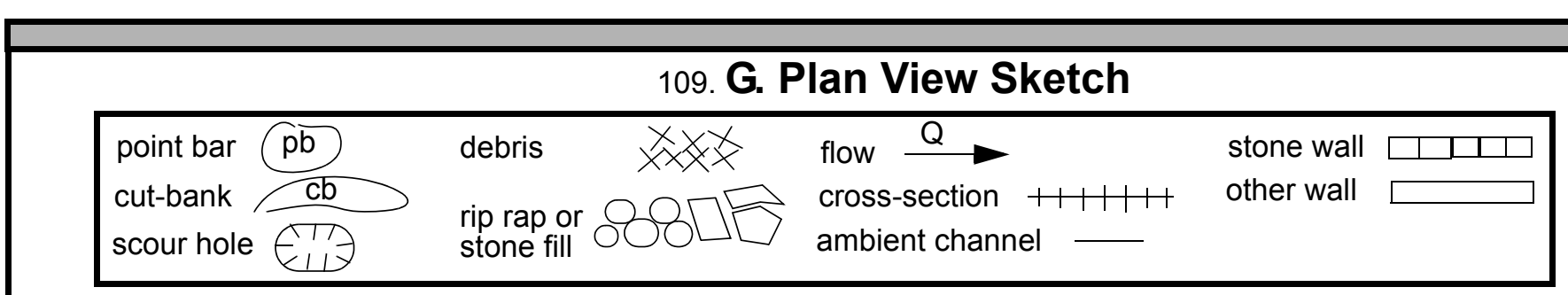


APPENDIX F:

SCOUR COMPUTATIONS 
SCOUR COMPUTATIONS

\begin{tabular}{|c|c|c|c|}
\hline Structure Number: CONCTH00580033 & & Town: & CONCORD \\
\hline Road Number: & & County: & ESSEX \\
\hline MILES STREAM & & & \\
\hline Initials RLB & Checked: & MAI & \\
\hline nalysis of contraction scour, li & bed or $\mathrm{C}$ ] & Lear wa & \\
\hline Critical Velocity of Bed Material & converted & to Engl & sh units) \\
\hline (Richardson and others, 1995, p. 2 & $=2.65$ eq. 16) & & \\
\hline Approach Section & & & \\
\hline Characteristic & $100 \mathrm{yr}$ & $500 \mathrm{yr}$ & other Q \\
\hline Total discharge, cfs & 2550 & 3530 & 1810 \\
\hline Main Channel Area, ft2 & 713 & 790 & 586 \\
\hline Left overbank area, ft2 & 138 & 264 & 19 \\
\hline Right overbank area, ft2 & 21 & 48 & 1 \\
\hline Top width main channel, ft & 105 & 105 & 105 \\
\hline Top width L overbank, ft & 163 & 178 & 33 \\
\hline Top width $\mathrm{R}$ overbank, ft & 29 & 44 & 5 \\
\hline D50 of channel, ft & 0.1879 & 0.1879 & 0.1879 \\
\hline D50 left overbank, ft & -- & -- & -- \\
\hline D50 right overbank, ft & -- & -- & -- \\
\hline Y1, average depth, $M C$, ft & 6.8 & 7.5 & 5.6 \\
\hline Y1, average depth, LOB, ft & 0.8 & 1.5 & 0.6 \\
\hline $\mathrm{Y}^{1}$, average depth, ROB, ft & 0.7 & 1.1 & 0.2 \\
\hline Total conveyance, approach & 78273 & 98838 & 54042 \\
\hline Conveyance, main channel & 74565 & 88437 & 53709 \\
\hline Conveyance, LOB & 3068 & 8514 & 327 \\
\hline Conveyance, ROB & 640 & 1888 & 6 \\
\hline Percent discrepancy, conveyance & 0.0000 & -0.0010 & 0.0000 \\
\hline Qm, discharge, MC, cfs & 2429.2 & 3158.5 & 1798.8 \\
\hline Ql, discharge, LOB, cfs & 100.0 & 304.1 & 11.0 \\
\hline Qr, discharge, ROB, Cfs & 20.9 & 67.4 & 0.2 \\
\hline $\mathrm{Vm}$, mean velocity $\mathrm{MC}$, ft/s & 3.4 & 4.0 & 3.1 \\
\hline Vl, mean velocity, LOB, ft/s & 0.7 & 1.2 & 0.6 \\
\hline Vr, mean velocity, $R O B, f t / s$ & 1.0 & 1.4 & 0.2 \\
\hline Vc-m, crit. velocity, MC, ft/s & 8.8 & 9.0 & 8.6 \\
\hline Vc-l, crit. velocity, LOB, ft/s & ERR & ERR & ERR \\
\hline Vc-r, crit. velocity, ROB, ft/s & ERR & ERR & ERR \\
\hline Results & & & \\
\hline Live-bed(1) or Clear-Water(0) Cont & action Sc & our? & \\
\hline Main Channel & 0 & 0 & 0 \\
\hline Left Overbank & $\mathrm{N} / \mathrm{A}$ & $\mathrm{N} / \mathrm{A}$ & $\mathrm{N} / \mathrm{A}$ \\
\hline Right Overbank & $\mathrm{N} / \mathrm{A}$ & $\mathrm{N} / \mathrm{A}$ & $\mathrm{N} / \mathrm{A}$ \\
\hline
\end{tabular}


Clear water Contraction Scour in MAIN CHANNEL

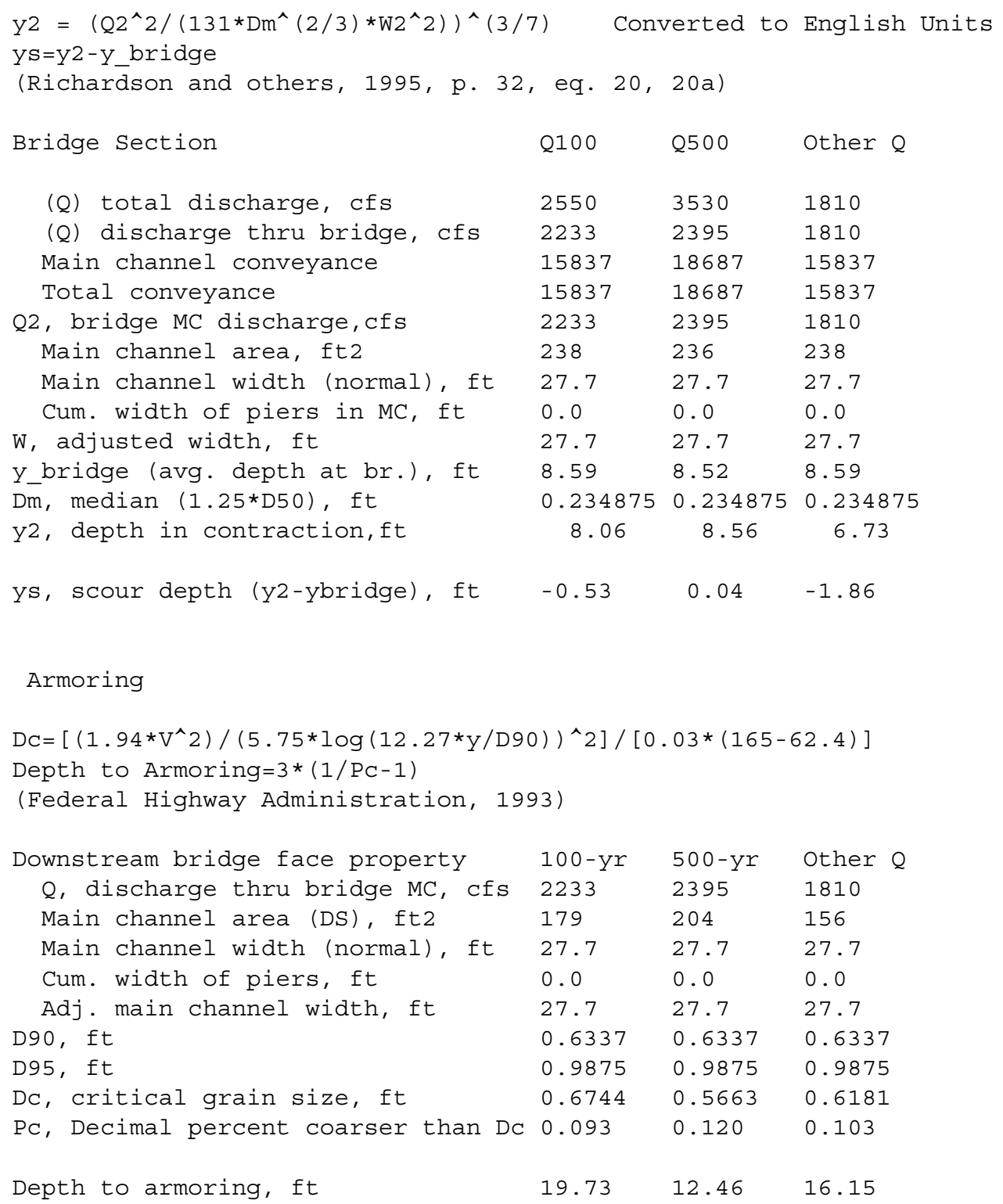




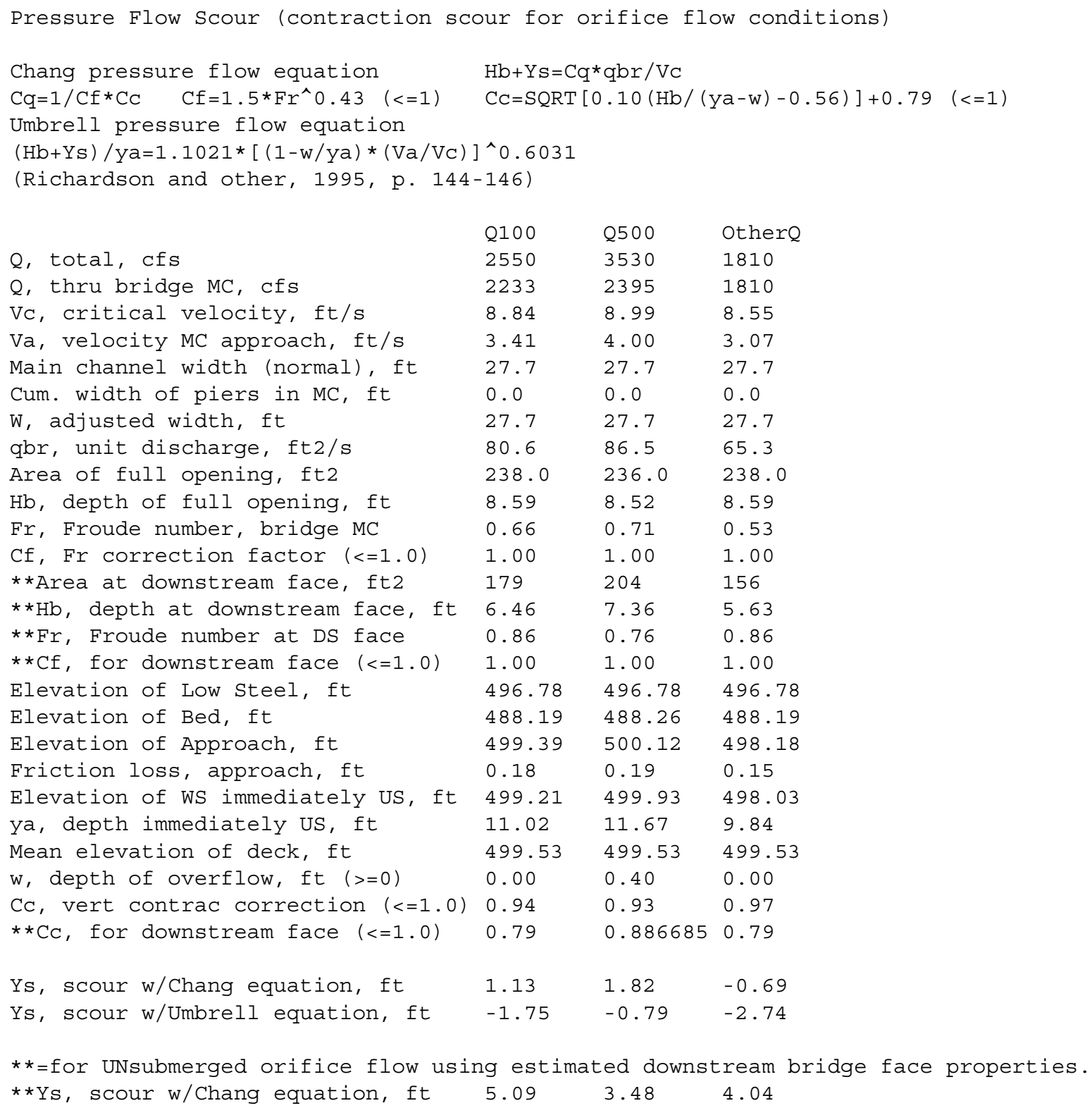




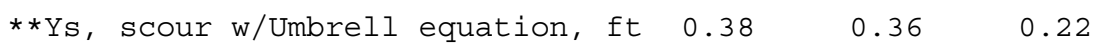

In UNsubmerged orifice flow, an adjusted scour depth using the Laursen equation results and the estimated downstream bridge face properties can also be computed (ys=y2-ybridgeDs)

$\begin{array}{lllll}\text { Y2, from Laursen's equation, ft } & 8.06 & 8.56 & 6.73 \\ \text { WSEL at downstream face, ft } & 495.21 & 495.88 & 494.57 \\ \text { Depth at downstream face, ft } & 6.46 & 7.36 & 5.63\end{array}$

Ys, depth of scour (Laursen), ft $1.60 \quad 1.20 \quad 1.10$

Abutment scour

Froehlich's Abutment Scour

$\mathrm{Ys} / \mathrm{Y} 1=2.27 * \mathrm{~K} 1 * \mathrm{~K} 2 *\left(\mathrm{a}^{\prime} / \mathrm{Y} 1\right)^{\wedge} 0.43 * \mathrm{Fr} 1 \wedge 0.61+1$

(Richardson and others, 1995, p. 48, eq. 28)

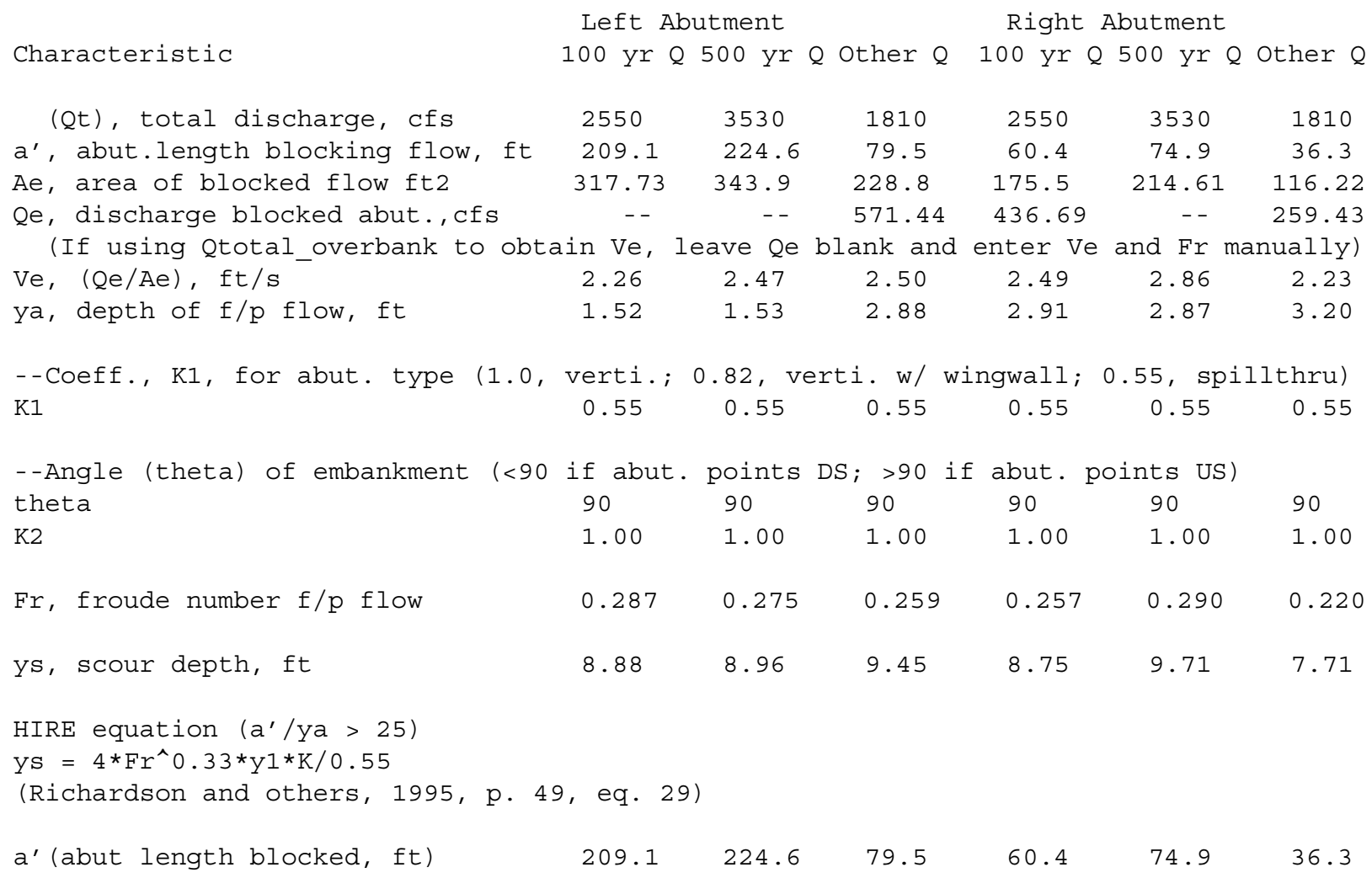




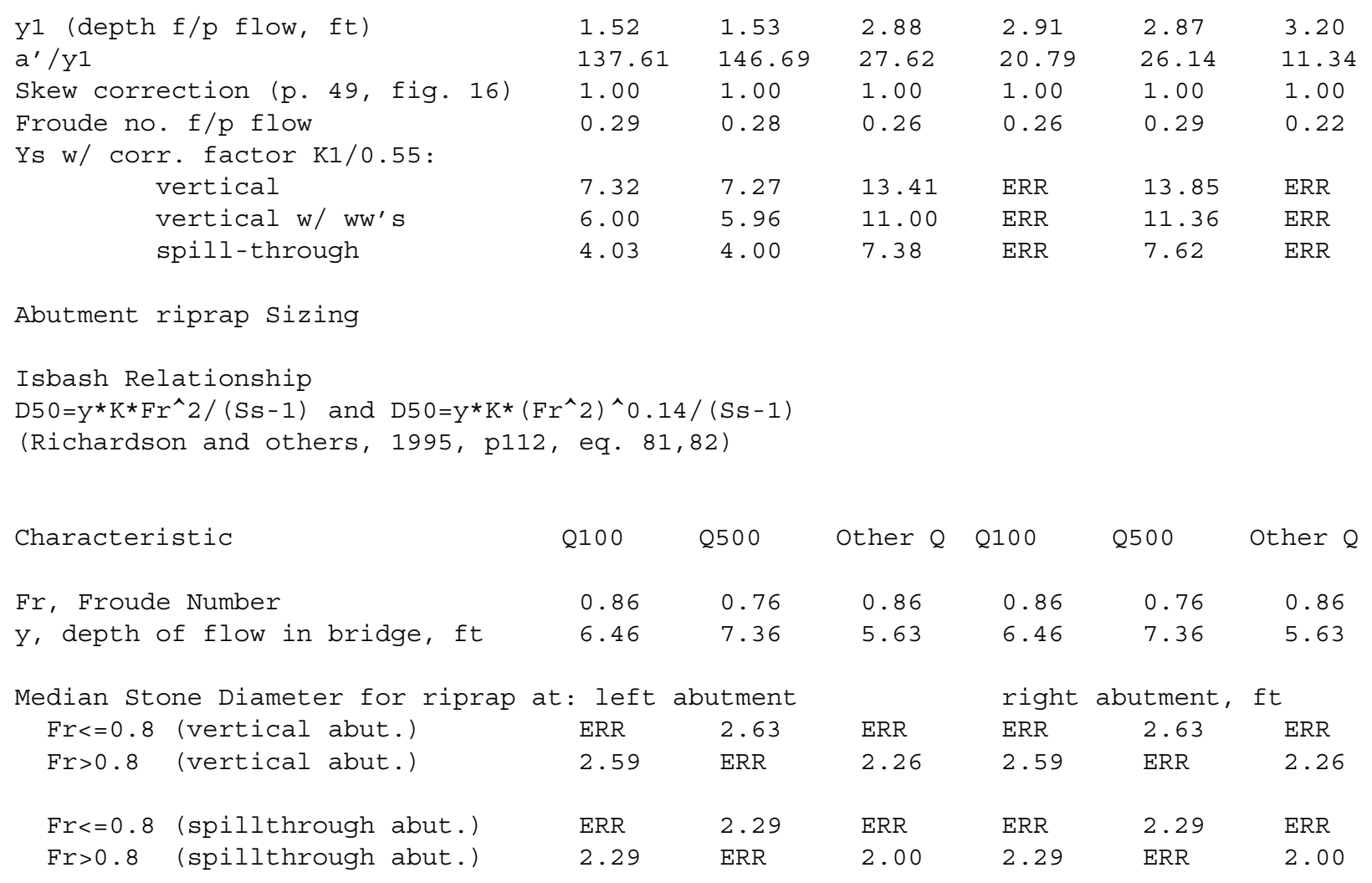

